OPEN ACCESS

Edited by:

Rasha Abu Eid,

University of Aberdeen,

United Kingdom

Reviewed by:

lain James Nixon,

National Health Service Scotland,

United Kingdom

Sven Brandau,

University of Duisburg-Essen,

Germany

Marija Kovacevic-Sarmiento, University of Duisburg-Essen,

Germany, in collaboration with

reviewer $S B$

*Correspondence:

Mohammed M. Al Qaraghuli m.alqaraghuli@simologics.co.uk

Specialty section:

This article was submitted to Head and Neck Cancer,

a section of the journal

Frontiers in Oncology

Received: 06 May 2020 Accepted: 03 November 2020 Published: 26 November 2020

Citation:

Al Qaraghuli MM (2020) Biotherapeutic Antibodies for the Treatment of Head and Neck Cancer:

Current Approaches and

Future Considerations of

Photothermal Therapies.

Front. Oncol. 10:559596.

doi: 10.3389/fonc.2020.559596

\section{Biotherapeutic Antibodies for the Treatment of Head and Neck Cancer: Current Approaches and Future Considerations of Photothermal Therapies}

\author{
Mohammed M. Al Qaraghuli ${ }^{1,2 *}$ \\ 1 SiMologics Ltd., Glasgow, United Kingdom, ${ }^{2}$ Department of Chemical and Process Engineering, University of Strathclyde, \\ Glasgow, United Kingdom
}

Head and neck cancer $(\mathrm{HNC})$ is a heterogeneous disease that includes a variety of tumors originating in the hypopharynx, oropharynx, lip, oral cavity, nasopharynx, or larynx. HNC is the sixth most common malignancy worldwide and affects thousands of people in terms of incidence and mortality. Various factors can trigger the development of the disease such as smoking, alcohol consumption, and repetitive viral infections. HNC is currently treated by single or multimodality approaches, which are based on surgery, radiotherapy, chemotherapy, and biotherapeutic antibodies. The latter approach will be the focus of this article. There are currently three approved antibodies against HNCs (cetuximab, nivolumab, and pembrolizumab), and 48 antibodies under development. The majority of these antibodies are of humanized (23 antibodies) or human (19 antibodies) origins, and subclass $\operatorname{lgG}_{1}$ represents a total of 32 antibodies. In addition, three antibody drug conjugates (ADCs: telisotuzumab-vedotin, indatuximab-ravtansine, and W0101) and two bispecific antibodies (GBR 1372 and ABL001) have been under development. Despite the remarkable success of antibodies in treating different tumors, success was limited in HNCs. This limitation is attributed to efficacy, resistance, and the appearance of various side effects. However, the efficacy of these antibodies could be enhanced through conjugation to gold nanoparticles (GNPs). These conjugates combine the high specificity of antibodies with unique spectral properties of GNPs to generate a treatment approach known as photothermal therapy. This approach can provide promising outcomes due to the ability of GNPs to convert light into heat, which can specifically destroy cancer cells and treat $\mathrm{HNC}$ in an effective manner.

Keywords: antibody, head and neck cancer, photothermal therapy, gold nanoparticles, gold nanorods 


\section{INCIDENCE, ETIOLOGY, AND TREATMENT}

Head and neck cancer (HNC) affects over 830,000 patients worldwide, and about 430,000 people had died from this disease in 2018 (1). This disease is highly heterogeneous and can affect the hypopharynx, oropharynx, lip, oral cavity, nasopharynx, or larynx. It is the sixth most common cancer, and associated with a high recurrence and poor 5 -year survival rate $(40-50 \%)$ (2). Tobacco and alcohol use are the main risk factors that increase the incidence of HNC (3). Strains 16 and 18 of human papillomavirus (HPV) are also linked with several cases of $\mathrm{HNC}(4)$, however, $\mathrm{HPV}^{+}$cancers have a better survival rate and reduced risk of recurrence compared with $\mathrm{HPV}^{-}$(4).

The most common treatment modalities for HNCs include surgery, radiotherapy (RT), chemotherapy (CT), and biotherapeutic antibodies. Early-stage tumors can be treated with single modality treatment such as surgery or RT (5), for patients with advanced-stage disease are normally treated with combined-modality therapy (6). Both CT and RT can be efficacious in treating HNCs, however, patients must withstand their severe side effects $(7,8)$. Surgery involves resection of the primary tumor with or without lymph nodal dissection, which can have a significant impact on eating, drinking, and talking, and patients will also need to cope with subsequent facial disfigurement (9). In certain cases surgery may involve removing the larynx, which will greatly affect communication (10), and have a negative impact on the patient's psychology and quality of life. The Food and Drug Administration (FDA) has approved different CTs, such as cisplatin, carboplatin, 5fluorouracil, docetaxel, methotrexate, and bleomycin, and three monoclonal antibodies (cetuximab, nivolumab, and pembrolizumab) for the treatment of HNCs. The current treatment standard for recurring or metastatic HNCs is based on cetuximab and platinum based cisplatin or carboplatin CT plus methotrexate and 5-flurouracil; which is further strengthened by surgery and RT, and occasionally augmented by paclitaxel and docetaxel (11). Cisplatin resistant, recurring, or metastatic HNCs could be treated through the inclusion of checkpoint inhibitor antibodies, pembrolizumab or nivolumab $(12,13)$.

Various review articles have focused on different treatment options for HNCs such as surgery (14-16), RT (17-20), CT (21$24)$, and immunotherapies (25-27). This article will specifically focus on analyzing biotherapeutic antibodies that are currently approved or being examined in different clinical trials. The main targets that have attracted several developed antibodies were analyzed in term of structural illustration and mechanism of action. In addition, the future perspective of using nanotechnology to enhance the efficacy of these antibodies is briefly outlined.

\section{ANTIBODY STRUCTURE}

B-lymphocyte cells are instructed by numerous immunogens, such as bacteria, viruses, fungi, parasites, cellular antigens, chemicals, and synthetic substances to differentiate into plasma cells (28). These plasma cells secrete glycoproteins, also known as antibodies, to protect our bodies against these antigens. The "Y" shaped antibody is generally comprising two heavy and two light polypeptide chains linked together by disulfide bonds. The light chain, which could be lambda $(\lambda)$ or kappa $(k)$, can be linked to any of the nine characterized heavy-chain subtypes to generate one of the antibody subclasses in humans $\left(\operatorname{IgG}_{1-4}, \operatorname{IgA}_{1-2}, \operatorname{IgM}\right.$, IgE, IgD) (29). The IgG class represents the majority of the licensed therapeutic antibodies and those still in the stage of development (30). The IgG antibody is composed of two identical antigen-binding fragments (Fabs) and one crystallizable region fragment $(\mathrm{Fc})$ (Figure 1). Each $\mathrm{Fab}$ contains the first two domains of the heavy ( $\mathrm{VH}$ and $\mathrm{CH} 1$ ) and light (VL and $\mathrm{CL}$ ) chains, while the $\mathrm{Fc}$ region consist of two $\mathrm{N}$-glycosylated $\mathrm{CH} 2$ and two $\mathrm{CH} 3$ domains (31). Antibodies are well known for their high specificity and selectivity that make them indispensable medicines to treat various diseases, especially cancer, and currently represent a major component of the pharmaceutical industry (32).

\section{ANTIBODIES AGAINST HEAD AND NECK CANCER}

Over the last two decades, our understanding of the molecular mechanisms underlying HNCs, and developments in molecular biology, have led to the development of different targeted therapeutic agents. HNCs can be generally prompted by a primary lesion or metastasize from another cancerous site leading to malignant tumor. Cancer stem cells are constantly addressed as one of the primary mediators of tumor aggressiveness, relapse, and malignancy $(33,34)$. Tumortargeting antibodies are generally used to recognize tumorspecific membrane proteins, and induce tumor-killing through Fc-driven innate immune responses, or block cell signaling (35).

Currently and to the best of our knowledge, there are 51 antibodies are being tested at preclinical or clinical trials against HNCs (Table 1). Of three of the tested antibodies (nivolumab, cetuximab, and pembrolizumab) were approved by regulatory authorities for the treatment of HNC. The main addressed targets were epidermal growth factor receptor (EGFR) (eight antibodies), programmed cell death protein 1 (PD-1) (six antibodies), programmed death-ligand 1 (PD-L1) (five antibodies), and receptor tyrosine-protein kinase erbB-3 (HER3) (four antibodies). In addition, two antibodies are being developed to each of the cytotoxic T-lymphocyte-associated protein 4 (CTLA4), HER2, c-Met, and vascular endothelial growth factor A (VEGF-A). Moreover, the developed antibodies were mainly of sub-class $\operatorname{IgG}_{1}$ (32 antibodies), followed by subclasses $\operatorname{IgG}_{4}$ (11 antibodies) and $\mathrm{IgG}_{2}$ (4 antibodies). The antibodies were developed as chimeric, humanized, human, or fusion proteins, which were represented by 5, 23, 19, and 2 antibodies, respectively. Besides the monoclonal antibodies, three antibody drug conjugates (ADCs: telisotuzumab-vedotin, indatuximab-ravtansine, and 


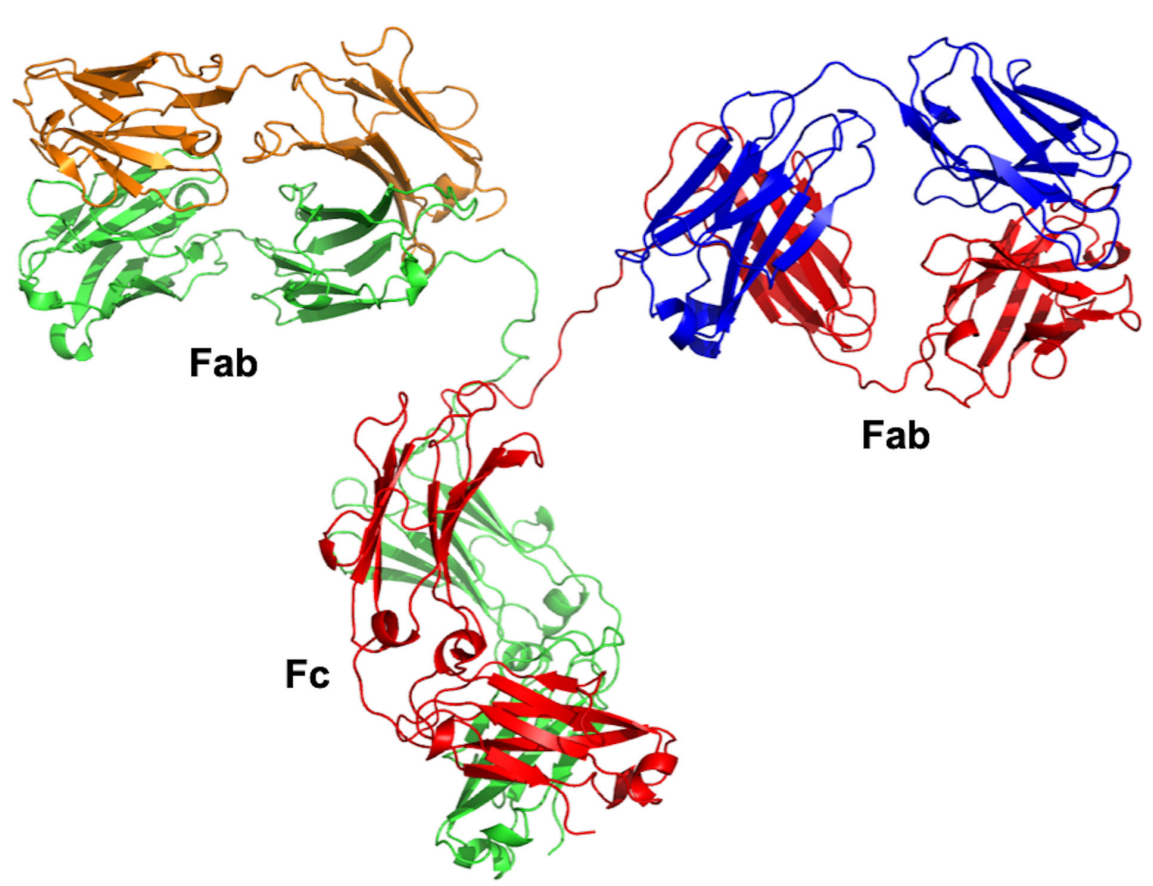

FIGURE 1 | Overall structure of IgG antibody. The crystal structure was obtained from the Protein Data Bank (PDB entry 1IGT). The lgG antibody is composed of two heavy chains (red and green) and two light chains (orange and blue). The crystal structure was viewed and analyzed using PyMOL (The PyMOL Molecular Graphics System, Version 2.4.0 Schrödinger, LLC.).

W0101) and two bispecific antibodies (GBR 1372 and ABL001) are also under development. The analysis will focus on two main targets that attracted the majority of the developed antibodies, as will be detailed in the following two sections.

Each listed antibody was described in term of type, class, targeted antigen, involved companies, as well as details of the clinical development stage based on information available on ClinicalTrials.gov.

\section{Anti-Epidermal Growth Factor Receptor Antibodies}

EGFR is a glycoprotein belonging to the ErbB receptor family, and it is composed of an extracellular ligand-binding domain, an intracellular tyrosine kinase domain, and a hydrophobic transmembrane segment (36). Under unstimulated conditions, the EGFR is predominantly available as an auto-inhibited, dimerization-incompetent, state at the cell membrane (37). EGFR can bind to different ligands [transforming growth factor alpha (TGF- $\alpha$ ), amphiregulin, and EGF] that can trigger receptor dimerization and subsequent auto activation of the tyrosine kinase from the intracellular domain of the receptor (38). These ligand-induced EGFR conformational changes can also recruit the endocytic machinery that facilitates receptor endocytosis, with $\sim 10$-fold higher internalization rates for ligand-bound than for unliganded EGFR (39).

EGFRs are expressed on the cell surface, and the mitogenactivated protein kinases (MAPK) pathway is the most important pathway in mediating the biological response of the
EGFR (40). This pathway interacts with over a hundred substrates to propagate various physiological responses, such as growth, proliferation, differentiation, migration, and inhibition of apoptosis $(41,42)$. EGFR is normally expressed as 40,000 to 100,000 receptors per cell (43), whereas in $80-90 \%$ of HNC cases EGFR and TGF- $\alpha$ are overexpressed by 1.7 -fold and 1.9 -fold, respectively (44). EGF and EGFR exert a critical role in cellular growth and differentiation both in healthy and cancerous tissues (45). The anomalous activation of the EGFR generate improved proliferation and additional tumor-promoting activities in different types of cancer, including HNC (36). Overexpression of EGFR can happen at early stage carcinogenesis of the head and neck, and can rise progressively together with other histological abnormalities, from hyperplasia to dysplasia, in situ carcinoma, and invasive carcinoma (46). Therefore, EGFR was selected as a potential target for anti-cancer antibodies.

Therapeutic antibodies were developed to target the extracellular domain of EGFR as demonstrated by cetuximab. This strategy was designed to avert receptor activation by endogenous ligands via competitive inhibition. In addition, it can internalize the antibody-receptor complex, and successively downregulate the EGFR expression (36). As a mono-therapy, cetuximab generates a cytostatic rather than a cytotoxic effect, which affected the clinical trials outcomes (47). The EXTREME trial (48) concluded that cetuximab plus platinum-fluorouracil CT can enhance the overall survival by 2.7 -month, and a $20 \%$ reduction in the relative risk of death, when compared to the chemotherapy-alone group. Secondary efficacy end points were also enhanced by the addition of cetuximab, demonstrated by a 
TABLE 1 | List of approved and underdevelopment antibodies against head and neck cancer (HNC).

\begin{tabular}{|c|c|c|c|c|c|c|}
\hline & Product name & Involved companies & Class & Target & Type & $\begin{array}{c}\text { Development stage } \\
\text { (ClinicalTrials.gov Identifier, active and recruiting) }\end{array}$ \\
\hline 1 & Cetuximab & $\begin{array}{l}\text { Medlmmune } \\
\text { (AstraZeneca), Merck \& } \\
\text { Co Inc, Bristol-Myers } \\
\text { Squibb AB }\end{array}$ & $\lg G 1$ & $\begin{array}{l}\text { Epidermal growth } \\
\text { factor receptor } \\
\text { (EGFR) }\end{array}$ & Chimeric & $\begin{array}{l}\text { In 2006, the FDA has approved cetuximab in } 2006 \text { and currently is } \\
\text { being used for: } \\
\text { - Locally or regionally advanced squamous cell carcinoma of the } \\
\text { head and neck in combination with radiation therapy. } \\
\text { - Recurrent locoregional disease or metastatic squamous cell } \\
\text { carcinoma of the head and neck in combination with platinum- } \\
\text { based therapy with fluorouracil. } \\
\text { - Recurrent or metastatic squamous cell carcinoma of the head } \\
\text { and neck progressing after platinum-based therapy. }\end{array}$ \\
\hline 2 & Pembrolizumab & Merck \& Co Inc & $\lg G 4$ & $\begin{array}{l}\text { Programmed cell } \\
\text { death protein } 1 \\
\text { (PD-1) }\end{array}$ & Humanized & $\begin{array}{l}\text { The FDA approved pembrolizumab in } 2019 \text { as a first-line treatment } \\
\text { of patients with metastatic or unresectable recurrent head and } \\
\text { neck squamous cell carcinoma. }\end{array}$ \\
\hline 3 & Nivolumab & $\begin{array}{l}\text { Bristol-Myers Squibb } \\
\text { (Medarex) and Ono } \\
\text { Pharmaceutical }\end{array}$ & $\lg G 4$ & PD-1 & Human & $\begin{array}{l}\text { The FDA approved nivolumab in } 2016 \text { for patients with metastatic } \\
\text { or recurrent squamous cell carcinoma of the head and neck } \\
\text { (SCCHN) following progression on platinum-based therapy. }\end{array}$ \\
\hline 6 & Atezolizumab & Genentech (Roche) & $\lg G 1$ & $\begin{array}{l}\text { Programmed } \\
\text { death-ligand } 1 \\
\text { (PD-L1) }\end{array}$ & Humanized & $\begin{array}{l}\text { NCT03708224 (phase II) NCT02423863 (phase II) NCT03818061 } \\
\text { (phase II) NCT03829501 (phase I/II) NCT03452137 (phase III) } \\
\text { NCT03289962 (phase I) NCT03212469 (phase I/II) NCT03170960 } \\
\text { (phase I/II) NCT03313804 (phase II) NCT03841110 (phase I } \\
\text { NCT03386721 (phase II) NCT03228667 (phase II) }\end{array}$ \\
\hline 7 & Avelumab & $\begin{array}{l}\text { Merck KGaA and Pfizer } \\
\text { Inc }\end{array}$ & $\lg \mathrm{G}_{1}$ & PD-L1 & Human & $\begin{array}{l}\text { NCT03844763 (phase I/II) NCT03494322 (phase II) NCT04052204 } \\
\text { (phase II) NCT03260023 (phase I/II) NCT02999087 (phase III) } \\
\text { NCT03409458 (phase I/II) NCT03498378 (phase I) NCT02952586 } \\
\text { (phase III/terminated due to lack of efficacy) } \\
\text { NCT02554812 (phase II) NCT03228667 (phase II) }\end{array}$ \\
\hline 8 & Tremelimumab & $\begin{array}{l}\text { Pfizer and Medlmmune } \\
\text { (AstraZeneca) }\end{array}$ & $\lg G 2$ & $\begin{array}{l}\text { Cytotoxic T- } \\
\text { lymphocyte- } \\
\text { associated protein } \\
4 \text { (CTLA-4) }\end{array}$ & Human & $\begin{array}{l}\text { NCT03019003 (phase I/II) NCT02551159 (phase III) } \\
\text { NCT02999087 (phase III) NCT02369874 (phase III) NCT03283605 } \\
\text { (phase I/II) NCTO2319044 (phase II) NCT03212469 (phase I/II) } \\
\text { NCT03426657 (phase II) NCT03624231 (phase II) NCT03518606 } \\
\text { (phase I/II) NCTO3292250 (phase II) NCT03522584 (phase I/II) } \\
\text { NCT02643303 (phase I/II) NCT03509012 (phase I) NCT03529422 } \\
\text { (phase I) }\end{array}$ \\
\hline 11 & Durvalumab & $\begin{array}{l}\text { Medlmmune } \\
\text { (AstraZeneca) }\end{array}$ & $\lg G 1$ & PD-L1 & Human & $\begin{array}{l}\text { NCT03019003 (phase I/II) NCT03162224 (phase I/II) } \\
\text { NCT02291055 (phase I/II) NCT02997332 (phase I) NCT02551159 } \\
\text { (phase III) NCT03829007 (phase I/II) NCT02369874 (phase III) } \\
\text { NCT03737968 (phase II) NCT03051906 (phase I/II) NCTO3258554 } \\
\text { (phase II/III) NCT03691714 (phase II) NCT02207530 (phase II) } \\
\text { NCT02319044 (phase II) NCT03292250 (phase II) NCT02318277 } \\
\text { (phase I/II) NCT02423863 (phase II) NCT03518606 (phase I/II) } \\
\text { NCT02499328 (phase I/II) NCT04262388 (phase II) NCT03983954 } \\
\text { (phase I) NCT03212469 (phase I/II) NCT03739931 (phase I) }\end{array}$ \\
\hline 12 & Tomuzotuximab & $\begin{array}{l}\text { Glycotope GmbH, } \\
\text { Octapharma AG }\end{array}$ & $\lg G 1$ & EGFR & Human & NCT02052960 (phase II) \\
\hline 13 & Monalizumab & $\begin{array}{l}\text { Innate Pharma SA and } \\
\text { AstraZeneca }\end{array}$ & $\operatorname{lgG} 4$ & $\begin{array}{l}\text { CD94/NK group } 2 \\
\text { member A } \\
\text { (NKG2A) }\end{array}$ & Humanized & NCT02643550 (phase I/II) \\
\hline 14 & Utomilumab & MorphoSys AG, Pfizer Inc & $\lg G 2$ & CD137 (4-1BB) & Human & NCT02554812 (phase II) \\
\hline 15 & Cixutumumab & ImClone Systems (Eli Lilly) & $\lg G 1$ & $\begin{array}{l}\text { Insulin-like growth } \\
\text { factor } 1 \text { (IGF-1) } \\
\text { receptor }\end{array}$ & Human & NCT00617734 (phase Il; completed) \\
\hline 16 & Duligotuzumab & Genentech (Roche) & $\lg \mathrm{G}_{1}$ & HER3 & Humanized & NCT01911598 (phase I; completed) \\
\hline
\end{tabular}


TABLE 1 | Continued

\begin{tabular}{|c|c|c|c|c|c|c|}
\hline & Product name & Involved companies & Class & Target & Type & $\begin{array}{c}\text { Development stage } \\
\text { (ClinicalTrials.gov Identifier, active and recruiting) }\end{array}$ \\
\hline 17 & PF04518600 & Pfizer & $\lg G 2$ & $\begin{array}{l}\text { OX40 protein } \\
\text { (CD134) }\end{array}$ & Human & NCT02315066 (phase I) \\
\hline 18 & $\begin{array}{l}\text { IPH2102 } \\
\text { (Lirilumab) }\end{array}$ & $\begin{array}{l}\text { Innate Pharma SA and } \\
\text { Bristol-Myers Squibb AB }\end{array}$ & $\lg G 4$ & KIR2DL1/2/3 & Human & EU clinical trial: CA223-001 (phase I/II) \\
\hline 19 & Spartalizumab & Novartis & $\lg G 4$ & PD-1 & Humanized & NCT04213404 (phase I) NCT04000529 (phase I) \\
\hline 20 & $\begin{array}{l}\text { Sym004 (two } \\
\text { mAbs, } \\
\text { futuximab, and } \\
\text { modotuximab) }\end{array}$ & Symphogen A/S & $\lg G 1$ & EGFR & Chimeric & NCT01417936 (phase Il; completed) \\
\hline 21 & Ficlatuzumab & AVEO Oncology & $\lg G 1$ & $\begin{array}{l}\text { Human } \\
\text { hepatocyte } \\
\text { growth factor/ } \\
\text { scatter factor } \\
\text { (HGF/SF) ligand }\end{array}$ & Humanized & NCT03422536 (phase II) \\
\hline 24 & $\begin{array}{l}\text { Cemiplimab- } \\
\text { rwlc }\end{array}$ & Regeneron and Sanofi & $\operatorname{lgG} 4$ & PD-1 & Human & NCT04242173 (phase II) \\
\hline 25 & Dalantercept & Acceleron Pharma Inc & $\begin{array}{l}\text { Fc of } \\
\lg G 1\end{array}$ & $\begin{array}{l}\text { Activin receptor- } \\
\text { like kinase } 1 \\
\text { (ALK1) }\end{array}$ & $\begin{array}{l}\text { ALK1-FC fusion } \\
\text { protein }\end{array}$ & NCT01458392 (phase II; completed) \\
\hline 26 & $\begin{array}{l}\text { FRMD4A } \\
\text { antibody }\end{array}$ & $\begin{array}{l}\text { Cancer Research } \\
\text { Technology }\end{array}$ & $\begin{array}{l}\text { Not } \\
\text { specified }\end{array}$ & $\begin{array}{l}\text { FERM domain } \\
\text { containing } 4 \mathrm{~A} \\
\text { (FRMD4A) }\end{array}$ & Not specified & Preclinical \\
\hline 27 & Zalutumumab & Genmab A/S & $\lg G 1$ & EGFR & Human & $\begin{array}{l}\text { NCT00401401 (phase I/II; terminated) } \\
\text { NCT00707655 (phase I/II; terminated) } \\
\text { NCT01054625 (phase I/II; completed) } \\
\text { NCT00542308 (phase II; completed) } \\
\text { NCT00496652 (phase III; completed). }\end{array}$ \\
\hline 30 & ABL001 & ABL Bio & $\begin{array}{l}\text { IgG1- } \\
\text { ScFv }\end{array}$ & $\begin{array}{l}\text { VEGF/DLL4 (Delta } \\
\text { Like Canonical } \\
\text { Notch Ligand 4) }\end{array}$ & $\begin{array}{l}\text { Bispecific } \\
\text { antibody } \\
\text { (humanized } \\
\text { bevacizumab } \\
\text { and a DII4- } \\
\text { targeting ScFv) }\end{array}$ & NCT03292783 (phase I) \\
\hline 31 & Panitumumab & Abgenix Inc and Amgen & $\lg G 2$ & EGFR & Human & $\begin{array}{l}\text { NCT02415881 (phase I) NCT03733210 (phase I) NCT03405142 } \\
\text { (phase I) }\end{array}$ \\
\hline 32 & Enoblituzumab & MacroGenics & $\lg G 1$ & CD276 (B7-H3) & Humanized & NCT04129320 (phase II/III) NCT02475213 (phase I) \\
\hline 33 & Bavituximab & Peregrine Pharmaceuticals & $\lg G 1$ & Phosphatidylserine & Chimeric & NCT04150900 (phase I) \\
\hline 34 & $\begin{array}{l}\text { Telisotuzumab } \\
\text { vedotin (ABBV- } \\
\text { 399) }\end{array}$ & AbbVie & $\lg \mathrm{G} 1$ & $\begin{array}{l}\text { Tyrosine-protein } \\
\text { kinase Met (c-Met) }\end{array}$ & $\begin{array}{l}\text { Humanized ADC } \\
\text { (Ab-MMAE) }\end{array}$ & Preclinical \\
\hline 35 & $\begin{array}{l}\text { Budigalimab } \\
\text { (ABBV-181) }\end{array}$ & AbbVie & $\lg G 1$ & PD-L1 & Humanized & NCT04196283 (phase I) NCT03000257 (phase I) \\
\hline 36 & Cosibelimab & Checkpoint Therapeutics & $\lg G 1$ & PD-L1 & Human & NCT03212404 (phase I) \\
\hline 37 & CPI-006 & Corvus Pharmaceuticals & $\lg G 1$ & $\begin{array}{l}\text { CD73 (NT5E: } \\
\text { ecto-5'- } \\
\text { nucleotidase) }\end{array}$ & Humanized & NCT03454451 (phase I) \\
\hline 38 & Hu5F9-G4 & Forty Seven, Inc. & $\lg G 4$ & CD47 & Humanized & NCT02953782 (phase I) \\
\hline 39 & W0101 & Pierre Fabre & $\lg G 1$ & $\begin{array}{l}\text { Insulin-like growth } \\
\text { factor } 1 \text { receptor } \\
\text { (IGF-1R) }\end{array}$ & $\begin{array}{l}\text { Humanized ADC } \\
\text { (Ab-auristatin) }\end{array}$ & NCT03316638 (phase I/II) \\
\hline
\end{tabular}


TABLE 1 | Continued

\begin{tabular}{|c|c|c|c|c|c|c|}
\hline & Product name & Involved companies & Class & Target & Type & $\begin{array}{c}\text { Development stage } \\
\text { (ClinicalTrials.gov Identifier, active and recruiting) }\end{array}$ \\
\hline 40 & $\begin{array}{l}\text { Indatuximab } \\
\text { ravtansine (BT- } \\
\text { 062) }\end{array}$ & ImmunoGen & $\lg G 4$ & $\begin{array}{l}\text { CD138 } \\
\text { (syndecan-1) }\end{array}$ & $\begin{array}{l}\text { Chimeric ADC } \\
\text { (Ab-ravtansine) }\end{array}$ & Preclinical \\
\hline 41 & $\begin{array}{l}\text { Tislelizumab } \\
\text { (BGB-A317) }\end{array}$ & BeiGene & $\lg G 4$ & PD-1 & Humanized & $\begin{array}{l}\text { NCT03430843 (phase III) NCT03783442 (phase III) NCT03957590 } \\
\text { (phase III) NCT03924986 (phase III) }\end{array}$ \\
\hline 42 & GBR 1372 & Glenmark Pharmaceuticals & $\begin{array}{l}\text { Not } \\
\text { specified }\end{array}$ & EGFRxCD3 & $\begin{array}{l}\text { Bispecific } \\
\text { antibody }\end{array}$ & Preclinical \\
\hline 44 & $\begin{array}{l}\text { GA201 } \\
\text { (RG7160): }\end{array}$ & Roche & $\lg G 1$ & EGFR & Humanized & NCT00721266 (phase I; completed) \\
\hline 45 & LJM716 & Novartis AG & $\lg G 1$ & HER3 & Human & $\begin{array}{l}\text { NCT01598077 (phase I; completed) } \\
\text { NCT01822613 (phase I; completed) }\end{array}$ \\
\hline 46 & Siltuximab & $\begin{array}{l}\text { Centocor, Inc (Janssen } \\
\text { Biotech). }\end{array}$ & $\lg G 1$ & IL6 & Chimeric & NCT00841191 (phase I/II) \\
\hline 49 & Trastuzumab & Genentech (Roche) & $\lg G 1$ & HER2 & Humanized & NCT00004163 (phase II) NCT02627274 (phase I) \\
\hline 50 & Pertuzumab & Genentech (Roche) & $\lg \mathrm{G} 1$ & HER2 & Humanized & NCT02465060 (phase II) \\
\hline 51 & Onartuzumab & Genentech (Roche) & $\lg G 1$ & c-Met & Humanized & $\begin{array}{l}\text { Preclinical (Fab fragments with murine variable domains fused to } \\
\text { human IgG1 constant domains) }\end{array}$ \\
\hline
\end{tabular}

Each listed antibody was described in term of type, class, targeted antigen, involved companies, as well as details of the clinical development stage based on information available on ClinicalTrials.gov.

2.3-month prolongation of progression-free survival. The best perceived response rate $(20 \%)$ was at the lower end of the range usually reported for cisplatin-based therapy; this could be attributed to the fact that nearly one third of the patients received carboplatin, which is connected with lesser response rates than cisplatin $(49,50)$. The side effect profile in the chemotherapy alone group was typical of that for the combination of platinum plus fluorouracil $(49,51)$. These side effects are generally exemplified by neurotoxicity, ototoxicity, and renal toxicity (52). In 2006, cetuximab was approved by the FDA to treat HNCs, and currently being used for different indications
(Table 1). The US patents of cetuximab expired in 2016 (EU patents expired in 2014) (53). North American marketing rights of biosimilar cetuximab were transferred from Bristol-Myers Squibb to Eli Lilly in 2015. In addition, different companies are developing biosimilar versions of cetuximab (Table 2).

Besides Cetuximab there are seven other antibody-based projects that are being developed against EGFR, including tomuzotuximab, Sym004, Zalutumumab, nimotuzumab, GA201 (RG7160), GBR 1372, and panitumumab (Table 1). The structures of nimotuzumab, panitumumab, and cetuximab were crystallized and deposited in the Protein Data Bank (PDB)

TABLE 2 | Cetuximab biosimilars.

\begin{tabular}{|c|c|c|c|}
\hline & Product name & Development stage & Involved company \\
\hline 1 & Cetuximab biosimilar ONS1055 & Preclinical & Oncobiologics and Outlook Therapeutics \\
\hline 2 & Cetuximab biosimilar RPH0O2 & Phase III & R-Pharm \\
\hline 3 & Cetuximab biosimilar ONS1055 & Preclinical & Viropro, Oncobiologics, and Outlook Therapeutics \\
\hline 4 & Cetuximab biosimilar ABP494 & Preclinical & Actavis, Allergan, and Amgen \\
\hline 5 & Cetuximab biosimilar HLX05 & Preclinical & Shanghai Henlius Biotech Inc \\
\hline 6 & Cetuximab biosimilar ABP494 & Preclinical & Actavis, Allergan, and Amgen \\
\hline 7 & Cetuximab platform & Research & PlantForm Corporation \\
\hline 8 & Cetuximab biosimilar CT-P15 & Research & Celltrion \\
\hline 9 & Cetuximab biosimilar BNV003 & Research & Bionovis SA \\
\hline 10 & Cetuximab platform & Research & PharmaPraxis \\
\hline 11 & Cetuximab biosimilar CMAB009 & Phase $|/| I / I I \mid$ & Mabtech, Shanghai Zhangjiang Biotechnology, and Sinomab \\
\hline 12 & Cetuximab biosimilar KL 140 & Phase $1 / I / / I I$ & Sichuan Kelun Pharmaceutical Research Institute \\
\hline 13 & Cetuximab biosimilar CDP-1 & Phase $|/| I / I I \mid$ & Dragonboat Biopharmaceutical \\
\hline 14 & Cetuximab biosimilar (STI-001) & Phase III & Mabtech \\
\hline 15 & Cetuximab biosimilar & Research & BioXpress Therapeutics \\
\hline
\end{tabular}


as 3GKW, 5SX4, and 1YY9, respectively. Both panitumumab, and cetuximab were crystallized with EGFR, so their crystal structures were aligned to demonstrate the binding interaction (Figure 2). These two antibodies have shared and overlapped epitope on the EGFR surface.

\section{Immune Checkpoint Inhibitors}

Circulating $\mathrm{T}$ lymphocytes normally examine the identity of other cells in the body to differentiate self from non-self antigens are therefore referred to as "checks." This is achieved when a receptor binds to an equivalent ligand on a host cell, which will enable the $\mathrm{T}$ cells to identify it as a host cell, and prevents the triggering of an immune response (54). The main receptors involved in this type of immunological response are PD-1 (55), CTLA-4 (56), ICOS (57), OX40 (58), TIM-3 (59), and many others (60). We will focus on two main targets, PD-1/PD-L1 and CTLA-4, against which many anti-HNC antibodies are being developed.

PD-1 (CD279) is a type I transmembrane receptor with extracellular domains comparable with canonical immunoglobulin, and is responsible for signal transduction to intracellular domains (61). PD-1 is expressed at the cell surface of different cells, like T cells, monocytes, B cells, natural killer T cells, and dendritic cells (62). PD-1 receptor can interact with two ligands, PD-L1 (CD274) and PD-L2 (CD273), which are also expressed on cell surface like immunoglobulin transmembrane receptors (63). PD-L1 is controlled by external stimuli and constitutively present on both hematopoietic and non-hematopoietic cells (64), while PD-L2 is expressed inducibly on the surface of immune cells such as macrophages, dendritic cells, and mast cells (65). PD-1/PD-L1

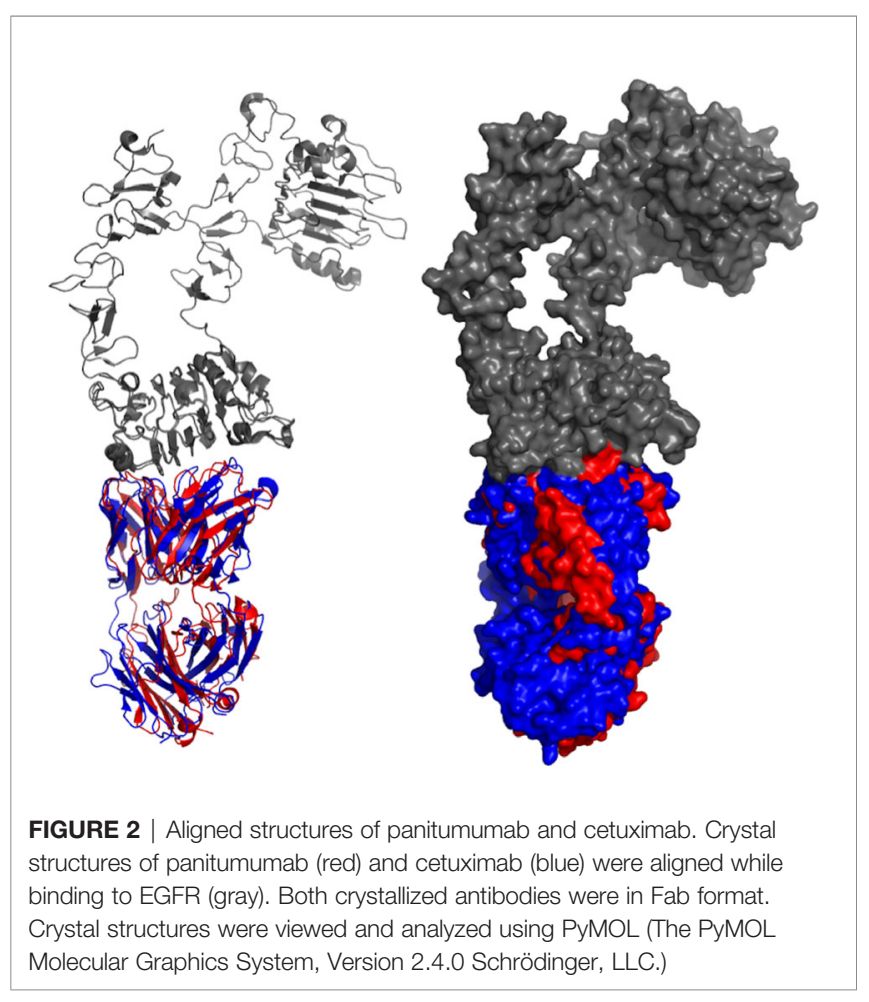

system in cancer impedes proliferation of T lymphocytes, release of cytokines, and cytotoxicity, which empower cancer cells to deceive the host $\mathrm{T}$ cells, and evades an immune response that can potentially destroy these cells (66).

The initial immunotherapeutic agents to reveal indication of response durability and survival advantage in platinum-pre-treated recurrent and metastatic $\mathrm{HNC}$ are anti-PD-1 monoclonal antibodies $(67,68)$. In 2016, the FDA licensed nivolumab and pembrolizumab for the treatment of platinum-based therapy resistant patients (Table 1). CheckMate 141 and KEYNOTE-040 are two completed phase III randomized trials that have shown the high effectiveness of nivolumab and pembrolizumab, when compared to methotrexate, docetaxel, or cetuximab $(13,69,70)$.

The outcomes of the KEYNOTE-048 study have confirmed the substantial effect of anti-PD-1 in the first line recurrent and metastatic HNC setting (71). The enhancement in survival revealed in the KEYNOTE-048 study, and the toxicity of the EXTREME regimen, has encouraged the FDA to approve Pembrolizumab to be used with CT as a first-line treatment of all patients with recurrent and metastatic HNC. Pembrolizumab was approved in 2019 as a single agent in cases with a PD-L1 Combined Positive Score (CPS) $\geq 1$ (72). In addition to these two approved antibodies, there are currently four antibodies underdevelopment against $\mathrm{PD}-1$ receptor, including toripalimab, cemiplimab-rwlc, tislelizumab, and spartalizumab, while five other antibodies were directed against the ligand 1 (PD-L1), including atezolizumab, avelumab, durvalumab, budigalimab, and cosibelimab. Details of the aforementioned antibodies are summarized in Table 1. The PDB portal includes crystal structures of three anti-PD-1 antibodies pembrolizumab (PDB entry: 5GGS), toripalimab (PDB entry: 6JBT), and nivolumab (PDB entry: 5GGR). Similarly, three anti-PD-L1 antibodies were deposited in the PDB [atezolizumab (PDB entry: 5XXY), avelumab (PDB entry: 5GRJ), and durvalumab (PDB entry: 5X8M)]. The six antibodies have bound to distinct epitopes on each of the PD-1 and PD-L1, as can be noticed through divergence of their aligned structures (Figure 3).

The other checkpoint target is CTLA-4 (CD152). As a B7/ CD28 family member, CTLA-4 can inhibit T cell functions (73). It is constitutively expressed by regulatory $\mathrm{T}$ cells (Tregs), and it can be upregulated upon activation by $\mathrm{CD}^{+} \mathrm{T}$ cells (74). CTLA4 primarily compete with $\mathrm{CD} 28$ receptors for binding to $\mathrm{B} 7$ ligands (B7-2/CD86 and B7-1/CD80) on the antigen presenting cells (APCs) (75). B7 ligands on APCs binds to CD28 receptors on T-cells and provide the necessary second activation signal. Nevertheless, CTLA-4 receptors bind to B7 ligands with greater affinity and at a lesser surface density, and in that way surpass CD28 receptors for binding with B7 ligands. This inhibition of the second pathway would thus lead to anergy in T-cells (76).

Human CTLA-4 includes a leader peptide and three domains: an extracellular $\mathrm{V}$ domain (116 amino acids), a transmembrane region (37 amino acids) and cytoplasmic tail ( 34 amino acid) that contains two tyrosine-based motifs (77). CTLA-4 has an essential function in controlling the immune responses in cancer and is contemplated as a prospective target against cancer. Preclinical studies have shown that the inhibition of CTLA-4 can enhance 

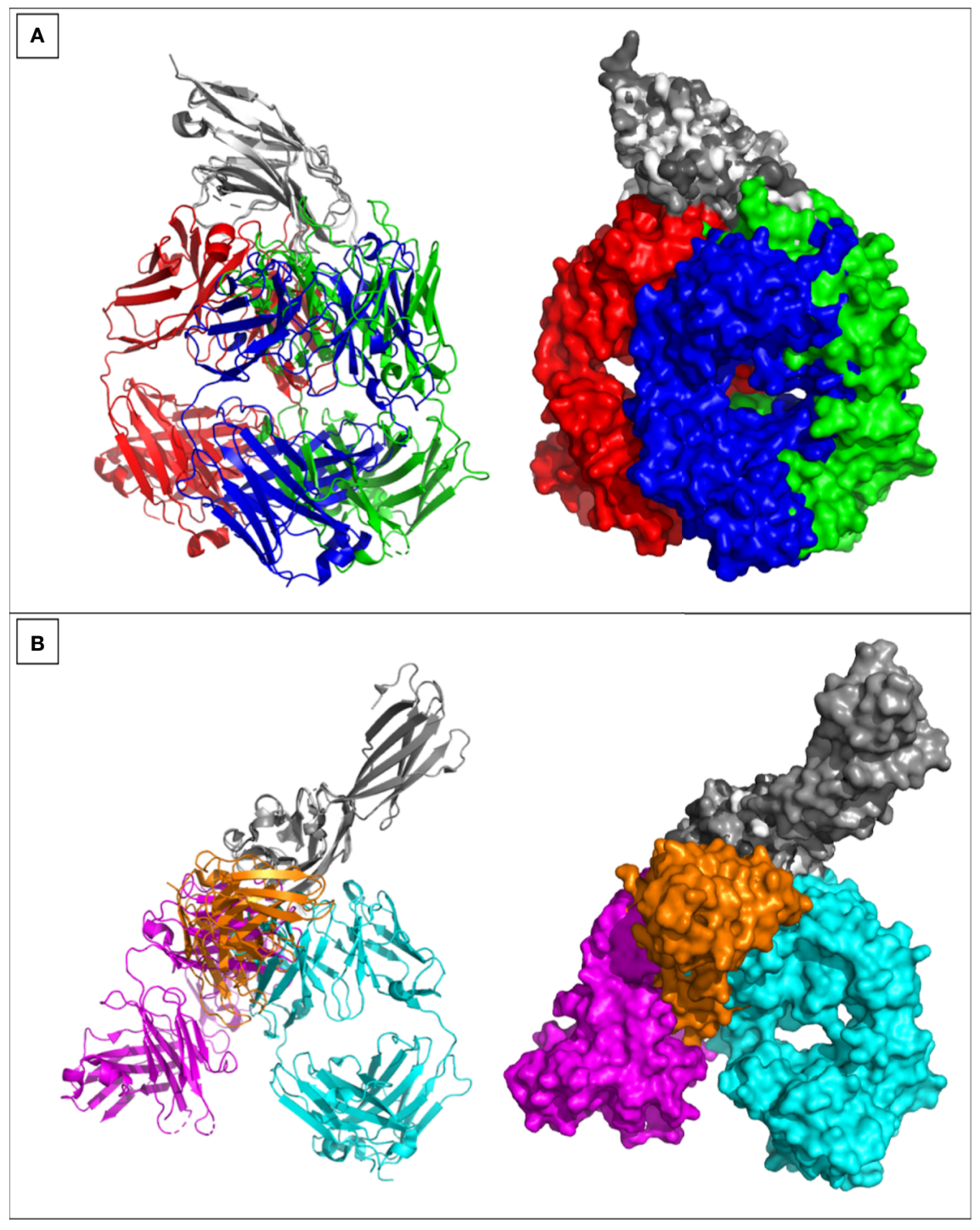

FIGURE 3 | Crystal structures of anti PD-1 and PD-L1 antibodies. Crystal structures of (A) Pembrolizumab (red), toripalimab (green), nivolumab (blue) were aligned while binding to PD-1 (gray). (B) Atezolizumab (magenta), avelumab (orange), durvalumab (cyan) were aligned while binding to PD-L1 (gray). All crystallized antibodies were as Fabs apart from avelumab that was crystallized as single chain variable fragment (ScFv). Crystal structures were viewed and analyzed using PyMOL (The PyMOL Molecular Graphics System, Version 2.4.0 Schrödinger, LLC.)

therapeutic immunity to cancer (78). At present, two antibodies (tremelimumab and ipilimumab) are being tested in clinical trials against HNC (Table 1). Crystal structures of these two antibodies (5GGV and 5TRU) were aligned to illustrate the binding model of shared epitope, but with slight deviation (Figure 4).

\section{Limitations of the Currently Offered Antibody-Based Approaches}

Despite the great potential of biotherapeutic antibodies in treating various types of cancer, the scenario is slightly more complicated in HNCs. HNC is very costly to be treated, and in the USA for example, it is considered to be the most expensive cancer to treat, with assessed costs of $\$ 96,000-\$ 150,000$ for multimodality treatment (79). Antibodies against HNCs have been hindered with limitations related to efficacy and safety.

Regarding the anti-EGFR antibodies, despite the $80-90 \%$ overexpression of EGFR in HNC, Cetuximab therapy is potent in only $10-20 \%$ of HNC patients (80). Thus, the clinical responses to Cetuximab might not be completely related to the EGFR expression levels in HNC (81). This absence of correlation is analogous to what was noted in colorectal cancer patients treated with Cetuximab (82). Nevertheless, these observations should be carefully interpreted as they could be attributed to variations in the methods adapted to measure the expression level of EGFR, such as staining protocols, tissue fixation techniques, storage time of these tissues, and type of 

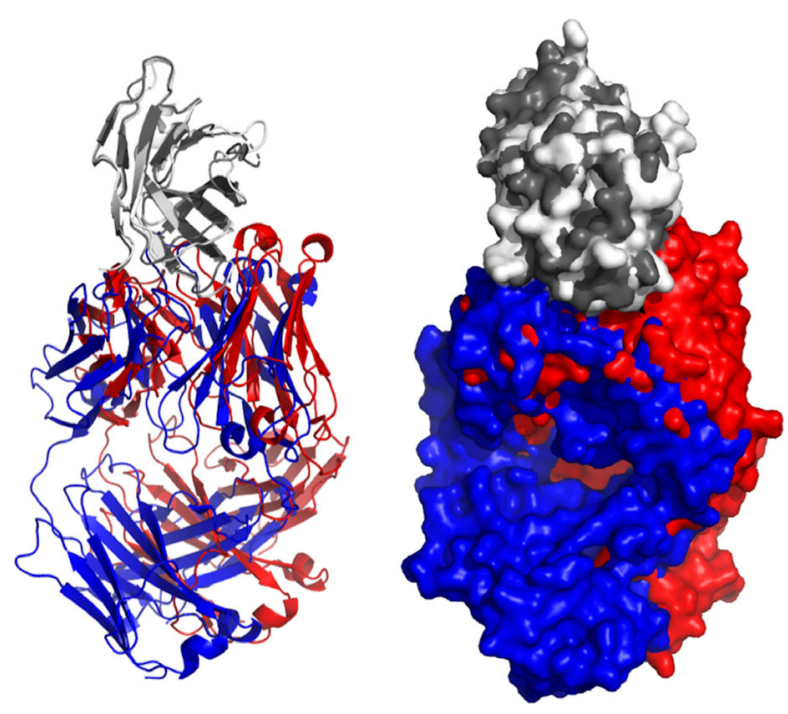

FIGURE 4 | Aligned structures of Tremelimumab and Ipilimumab. Crystal structures of Ipilimumab (red) and tremelimumab (blue) were aligned while binding to EGFR (gray). Both crystallized antibodies were in Fab format. Crystal structures were viewed and analyzed using PyMOL (The PyMOL Molecular Graphics System, Version 2.4.0 Schrödinger, LLC.)

preservation reagents (82). Another factor could be related to the utilization of primary tumor tissue to establish the patient's EGFR status, but it is the metastases stage, which is biologically distinct from the primary tumors, that is treated with cetuximab (83). Aside from these possible experimental variabilities, this lack of correlation could also lie in the prospective for cetuximab to induce antibodydependent cell-mediated cytotoxicity (ADCC), which can lead to indirect antitumor activity by the recruitment of cytotoxic host effector cells such as monocytes and natural-killer cells (84). Consequently, the EGFR expression level does not currently seem to have a predictive value, and the future development of a consistent immunocytochemistry technique or a reverse transcription polymerase chain reaction are certainly required.

HNCs can additionally develop resistance to cetuximab (85). Patients that are primarily responsive to anti-EGFR therapy frequently show resistance during the treatment course (86). Various factors allied with resistance have been recognized, such as ubiquitination and trafficking (87), overexpression and amplification of ErbB2 (88), KRAS mutations (89), polymorphism (90), changes in the microenvironment (91), reformed expression levels of VEGF (92), and altered expression levels of STAT3 (93). This resistance process can be signaling based, leading to activation of HER2, HER3, insulin growth factor receptor (IGFR), and c-Met $(94,95)$.

Another anti-EGFR is panitumumab, which was tested on patients with recurrent or metastatic HNC in the SPECTRUM trial (phase III) that examined cisplatin and fluorouracil with/ without panitumumab (96). Unlike the EXTREME study that tested cetuximab (48), the SPECTRUM trial on panitumumab has shown enhanced progression-free survival but not an overall survival. The noticed clinical variations between panitumumab and cetuximab exemplify the difficulty of obtaining a suitable anti-EGFR response in HNC. This complexity is not only limited to efficacy and resistance, but also extends to the appearance of various side effects.

EGFR is expressed at the epidermis basal layer, so it is anticipated that skin toxicity, such as acneiform eruptions, could be a major side effect (97). The dose-dependent rash was identified in over $50 \%$ of treated patients, especially on face, neck, retroauricular area, shoulders, and the upper trunk (98). In addition, cetuximab, is associated with different adverse events when used as a second line single agent, including rash, acne, dry skin, nail disorder, fever, nausea, vomiting, dyspnea, and other infusion-related reactions (99). The higher incidences of severe radiation dermatitis were observed following the clinical introduction of concurrent RT and cetuximab (100). For example, the EXTREME trial has shown nine cases of sepsis (4\%) in the cetuximab group, in contrast to one case $(<1 \%)$ in the CT-alone group (48).

On the other hand, immune checkpoint inhibitors (ICIs) show promising clinical benefit when generally compared to anti-EGFR antibodies. However, they can also cause a distinctive spectrum of side effects, influencing almost any organ. Shah et al. (101), have conducted a systematic review analyzing databases on patients with HNC, treated with ICIs, who developed immune-related adverse events (irAEs). The authors have identified 46 treatment-related adverse events from the pooled 791 patients, with at least 12 having essential consequence to irAEs. The most noticed adverse effects in patients receiving $\mathrm{PD}-1$ inhibitors were associated with the endocrine, cutaneous, and gastrointestinal systems.

Analysis of other clinical trials, which involved various ICIs, indicated that merely $\sim 15 \%$ of patients with refractory/metastatic HNC attained curable remissions and extended survival (102). According to The National Institute for Health and Care Excellence (NICE) report on nivolumab (103), clinical trial evidence showed that nivolumab enhanced the general survival by 2.6 months when compared with docetaxel, cetuximab, or methotrexate. However, there is uncertainty regarding the longerterm survival advantage after 2 years. Also, there is an ambiguity about its advantage in tumors expressing $<1 \%$ PD-L1 protein. Therefore, despite the current promising clinical outcomes from these ICIs, it is vital to note that some of the observed clinical responses happened in HNC patients who expressed negligible levels or no PD-L1 (13). Accordingly, the reason why not all patients show similar response to PD-1/PD-L1-targeted treatments are still undistinguishable. Furthermore, given the absence of any alternative treatment for HNC patients that are unresponsive to anti-PD-1 antibodies, there is a crucial unmet clinical requirement to find other choices if these resistance cases prevail.

\section{FUTURE PERSPECTIVES THROUGH NANOTECHNOLOGY}

Nanotechnology has rapidly progressed to provide pronounced promise in combating cancer (104). The large surface area to volume ratio of nanoparticles represents an important advantage (105). As this will enable the nanoparticle surfaces to be densely 
coated with antibodies, small molecules, peptides, or other molecules (106). Hence the coated moieties can bind and recognize specific cancer molecules through a multivalent effect that can enhance the efficacy and sensitivity of these conjugates. Therefore, nanotechnology-based diagnostics are being advanced as favorable methods (107).

Effective cancer treatments should distinguish between malignant from non-malignant cells, and to specifically destroy malignant cells (108). Nanoparticles can be used in this targeting process through passive or active approaches. The former is based on the enhanced permeability and retention effect of the cancer tissues that can lead to accumulation of these nanoparticles (109, 110). This high leakiness of tumor tissues is partially because malignant cells are not responsive to cell signaling required to organize vasculogenesis $(111,112)$. While active targeting involves specific recognition of antigens that are expressed on the surfaces of cancer cells to deliver these nanoparticles (113). In addition, surface modifications of nanoparticles can minimize uptake by the macrophage phagocytic system, and enhance circulation time (114). Consequently, nanoparticles can enhance the selectivity and effectiveness of these physical, chemical, and biological approaches to provoke cancer cell death, and with a minimum toxic effect on non-malignant cells. Different nanoparticles are currently in clinical trials for the treatment of and diagnosis of HNC (Table 3).

Nanoparticles could be adapted as dendrimers, liposomes, polymers, iron oxide, nanotubes, nanowires, and gold nanoparticles (GNPs) (115). Colloidal GNPs exhibit a distinctive localized surface plasmon resonance (LSPR) when a precise light wavelength encounters electrons on the GNPs surface (116). The light generates a combined coherent oscillation of these electrons, leading to the successive extinction of light. Scattering and absorption of the light relies on the medium of the colloidal GNPs as well as on their physical dimensions (117). These novel physico-chemical properties of GNPs have generated significant attention for developing both diagnostic and therapeutic approaches against cancer $(118,119)$. The implementation of these GNPs in combating cancer could be demonstrated through their photothermal capability. Various review articles have comprehensively detailed the concept, applications, safety, heating and cells-death mechanisms, synthesis and morphology, in vitro and in vivo efficacy, and physicochemical properties of these therapies (120-127). However, the basic principles of this approach are summarized and illustrated in this section to provide the reader with brief outlines of this potential field.

The concept of photothermal therapy is based on the application of a laser light at a specific wavelength to the surface of GNPs, which can trigger the surface electrons to be excited and resonate strongly, and conversion of light into heat swiftly happens (128). This results in bubble creation that can kill cells more effectively. The implemented laser light could be used in both the visible and near-infrared (NIR) wavelength region, and as pulsed or continuous wave (CW) (122). For instance, CW laser can trigger elevation of the cells temperature in the range of $41-47^{\circ} \mathrm{C}$ for tens of minutes, and this is known as hyperthermia (129). This state can cause permanent destruction of the cells through proteins denaturation and/or cell membrane damage (130).

GNPs have been investigated in different sizes and morphologies, for example nanorods (GNRs), nanospheres (GNSs), nanostars, hollow nanoshells, nanorings, and nanocages (131-135). The LSPR peaks of GNPs can be additionally turned to NIR region (136). The light absorption efficiency of GNPs in this region is high (extinction coefficient: $10^{-9} \mathrm{M}^{-1} \mathrm{~cm}^{-1}$ ), which enable the light to penetrate deeply into the tissues, and enhance the photothermal effect $(137,138)$. To modulate the LSPR to the NIR region, GNRs represent a great potential, due to their ability to present longitudinal and transverse surface plasmon absorption peaks, attributed to the length and diameter of the GNRs, respectively (139). This spectral location of the LSPR can be modified by altering the aspect ratio (AR) of GNRs (139). GNRs with different ARs generate different GNRs solutions' colors because of alterations in their response to light in the visible light spectrum (140).

Both GNSs and GNRs were used to generate photothermal effect within the visible or NIR region, respectively. El-Sayed et al., have initially used anti-EGFR antibody conjugated to GNSs (141) and GNRs (142) to diagnose and treat oral tumor cells in vitro using CW laser (514nm argon laser for GNSs; $800 \mathrm{~nm}$ Ti: sapphire laser for GNRs). They have shown that tumor cells targeted with the conjugates were destructed with 2-3 times

TABLE 3 | Nanoparticles-based approaches in head and neck cancer.

\begin{tabular}{|c|c|c|c|c|}
\hline & Nanoparticle (NP) type & Application & Responsible party & $\begin{array}{l}\text { Development stage (ClinicalTrials.gov } \\
\text { Identifier, active and recruiting) }\end{array}$ \\
\hline 1 & $\begin{array}{l}\text { Silica NP and experimental dye-labeled particle (dots), cRGDY-PEG- } \\
\text { Cy5.5-C dots }\end{array}$ & Imaging & $\begin{array}{l}\text { Memorial Sloan Kettering } \\
\text { Cancer Center }\end{array}$ & NCT02106598 (phase I/II, recruiting) \\
\hline 2 & Albumin stabilized NP and paclitaxel & Treatment & $\begin{array}{l}\text { University of Southern } \\
\text { California }\end{array}$ & NCT02495896 (phase I, active, not recruiting) \\
\hline 3 & Albumin stabilized NP and paclitaxel & Treatment & $\begin{array}{l}\text { Washington University } \\
\text { School of Medicine }\end{array}$ & NCT01566435 (phase II, active, not recruiting) \\
\hline 4 & Ferumoxytol (iron oxide) NP & Imaging & $\begin{array}{l}\text { M.D. Anderson Cancer } \\
\text { Center }\end{array}$ & NCT01895829 (phase I, active, not recruiting) \\
\hline 5 & $\begin{array}{l}\text { Silicon incorporated with quaternary ammonium polyethylenimine (PEI) } \\
\text { NP }\end{array}$ & Device & $\begin{array}{l}\text { Hadassah Medical } \\
\text { Organization }\end{array}$ & NCT01007240 (phase I, unknown) \\
\hline 6 & Hafnium oxide $\left(\mathrm{HfO}_{2}\right)$ nanoparticle & Treatment & Nanobiotix & NCT01946867 (phase I, unknown) \\
\hline 7 & Lipid NP encapsulating three mRNAs encoding human OX40L, & Treatment & Moderna Therapeutics & NCT03739931 (phase I, unknown) \\
\hline
\end{tabular}


lower laser power when compared to normal cells. In another study, a Ti:sapphire laser at $800 \mathrm{~nm}$ (100 femtosecond pulse duration, $1 \mathrm{kHz}$ repetition rate) was implemented to photothermally destroy oral cancer cells treated with antiEGFR antibodies conjugated to GNSs (143). Their results have demonstrated that the laser power required to destroy the cancer cells was nearly 20 times lower than that required to damage normal cells. Subsequently, various research articles have successfully tested the safety and efficacy of these GNRs based photothermal conjugates in mice, canines, and felines (144-146).

Despite the aforementioned advantages of GNPs, there is a possible long-term toxicity owing to sluggish tissue clearance, which is a factor that requires attention before GNPs can be used in vivo (147). Even with the assumption that these GNPs could accumulate passively at cancer cells due to extravasation of leaky tumor vasculature (148); it is still difficult to confirm this specificity and the overall elimination mechanism if GNRs were used alone. Low specificity could result in destruction of healthy tissues, which could produce additional side effects. Therefore, a more desired therapeutic outcome could be achieved through surface modification by coating and conjugation for precise targeting of these GNPs to reduce these side effects while maintaining their efficacy.

Another major limitation is related to cetyltrimethyl ammonium bromide (CTAB) that is broadly implemented in the synthesis of GNRs in seed-mediated growth $(149,150)$ or seedless technique (151). As a surfactant, CTAB binds to the GNRs surface and facilitates and stabilizes the formation of diverse structures (152). CTAB-stabilized GNPs can be cytotoxic, so they must be adjusted to evade cytotoxicity and inflammation. The cytotoxicity of $\mathrm{CTAB}$ could be avoided by replacing $\mathrm{CTAB}$ with other molecules like organothiol compounds (153), ligand exchange (154), or modifying the surface with polymer and silica-coating (155). In addition to the aforementioned surface modifications, GNPs can be coated with different materials to enhance the GNPs performance such as Bovine Serum Albumin (156), polyethylene glycol (157), and antibodies $(158,159)$. An alternative approach is also developed as GNRs free of CTAB $(160,161)$, which enhances the suitability of these GNRs for clinical settings.

\section{REFERENCES}

1. Bray F, Ferlay J, Soerjomataram I, Siegel RL, Torre LA, Jemal A. Global cancer statistics 2018: GLOBOCAN estimates of incidence and mortality worldwide for 36 cancers in 185 countries. CA Cancer J Clin (2018) 68 (6):394-424. doi: 10.3322/caac. 21492

2. Leemans CR, Braakhuis BJM, Brakenhoff RH. The molecular biology of head and neck cancer. Nat Rev Cancer (2011) 11(1):9-22. doi: 10.1038/ nrc2982

3. Hashim D, Genden E, Posner M, Hashibe M, Boffetta P. Head and neck cancer prevention: from primary prevention to impact of clinicians on reducing burden. Ann Oncol (2019) 30(5):744-56. doi: 10.1093/annonc/ mdz084

4. Koneva LA, Zhang Y, Virani S, Hall PB, McHugh JB, Chepeha DB, et al. HPV Integration in HNSCC Correlates with Survival Outcomes, Immune Response Signatures, and Candidate Drivers. Mol Cancer Res MCR (2018) 16(1):90-102. doi: 10.1158/1541-7786.MCR-17-0153
The conjugation of GNRs to antibodies represents a great advantage, since it will combine the high specificity of the antibody with the enormous optical potential of GNPs. However, the antibody target that can be used in this targeting process is of crucial importance. In addition, these antibodies should be carefully conjugated to GNRs to avoid loss of targeting efficacy due to steric hindrance. The conjugation process should be directed to a specific region within the antibody using a suitable linker, without affecting the specific binding regions for target detection. Therefore the size, shape, and surface modification of the implemented GNRs are key factors that will complement the overall success of these therapies.

\section{CONCLUSIONS}

HNC represents an immense clinical problem that requires special attention. The HNC treatment approaches are based on surgery, RT, CT, and biotherapeutic antibodies. Both RT and CT are well known for their severe side effects, and surgery can result in serious facial disfiguration and loose of ability to smell, speak, or taste. Antibodies have shown remarkable success in treating various types of cancer. Nevertheless, the complexity of HNC has relatively hindered this success. The three licensed antibodies against HNC are only being used in combination with other treatment modalities. Numerous monoclonal antibodies, ADCs, and bispecific antibodies are under development. The efficacy of these antibodies could be enhanced through conjugation to GNPs, and the generation of photothermal therapies. These photothermal therapies can specifically destroy cancer cells and treat $\mathrm{HNC}$ in an effective way. In order to gain a maximum photothermal effect the main three components (GNPs, linker, and the antibody) require careful optimizations.

\section{AUTHOR CONTRIBUTIONS}

The author confirms being the sole contributor of this work and has approved it for publication.

5. Grégoire V, Lefebvre J-L, Licitra L, Felip EEHNS-ESMO-ESTRO Guidelines Working Group. Squamous cell carcinoma of the head and neck: EHNSESMO-ESTRO Clinical Practice Guidelines for diagnosis, treatment and follow-up. Ann Oncol Off J Eur Soc Med Oncol (2010) 21 Suppl 5:v184-186. doi: 10.1093/annonc/mdq185

6. Cognetti DM, Weber RS, Lai SY. Head and Neck Cancer: An Evolving Treatment Paradigm. Cancer (2008) 113(70):1911-32. doi: 10.1002/ cncr.23654

7. Strojan P, Hutcheson KA, Eisbruch A, Beitler JJ, Langendijk JA, Lee AWM, et al. Treatment of late sequelae after radiotherapy for head and neck cancer Cancer Treat Rev (2017) 59:79-92. doi: 10.1016/j.ctrv.2017.07.003

8. Razmara F, Khayamzadeh M. An Investigation into the Prevalence and Treatment of Oral Mucositis After Cancer Treatment. Int J Cancer Management Kowsar (2019) 12. doi: 10.5812/ijcm.88405

9. Fang CY, Heckman CJ. Informational and support needs of patients with head and neck cancer: current status and emerging issues. Cancers Head Neck (2016) 1(1):15. doi: 10.1186/s41199-016-0017-6 
10. Mertl J, Žáćková E, Řepová B. Quality of life of patients after total laryngectomy: the struggle against stigmatization and social exclusion using speech synthesis. Disabil Rehabil Assist Technol (2018) 13(4):34252. doi: 10.1080/17483107.2017.1319428

11. Brana I, Siu LL. Locally advanced head and neck squamous cell cancer: treatment choice based on risk factors and optimizing drug prescription. Ann Oncol (2012) 23:x178-85. doi: 10.1093/annonc/mds322

12. Seiwert TY, Burtness B, Mehra R, Weiss J, Berger R, Eder JP, et al. Safety and clinical activity of pembrolizumab for treatment of recurrent or metastatic squamous cell carcinoma of the head and neck (KEYNOTE-012): an openlabel, multicentre, phase 1b trial. Lancet Oncol (2016) 17(7):956-65. doi: 10.1016/S1470-2045(16)30066-3

13. Ferris RL, Blumenschein GJ, Fayette J, Guigay J, Colevas AD, Licitra L, et al. Nivolumab for Recurrent Squamous-Cell Carcinoma of the Head and Neck. Massachusetts Med Soc (2016) 375:1856-67. doi: 10.1056/NEJMoa1602252

14. Tamaki A, Rocco JW, Ozer E. The future of robotic surgery in otolaryngology - head and neck surgery. Oral Oncol (2020) 101:104510. doi: 10.1016/j.oraloncology.2019.104510

15. Weber F, Schuss U, Sittel C. [Possibilities and limitations of palliative surgery in head and neck cancer patients]. HNO (2020) 687(7):498-502. doi: 10.1007/s00106-020-00817-0

16. Crowson MG, Ranisau J, Eskander A, Babier A, Xu B, Kahmke RR, et al. A contemporary review of machine learning in otolaryngology-head and neck surgery. Laryngoscope (2020) 130(1):45-51. doi: 10.1002/lary.27850

17. Kawashita Y, Soutome S, Umeda M, Saito T. Oral management strategies for radiotherapy of head and neck cancer. Jpn Dent Sci Rev (2020) 56(1):62-7. doi: 10.1016/j.jdsr.2020.02.001

18. Vissink A, Jansma J, Spijkervet FKL, Burlage FR, Coppes RP. Oral sequelae of head and neck radiotherapy. Crit Rev Oral Biol Med Off Publ Am Assoc Oral Biol (2003) 14(3):199-212. doi: 10.1177/154411130301400305

19. Overgaard J. Hypoxic modification of radiotherapy in squamous cell carcinoma of the head and neck-a systematic review and meta-analysis. Radiother Oncol J Eur Soc Ther Radiol Oncol (2011) 100(1):22-32. doi: 10.1016/j.radonc.2011.03.004

20. Schwartz DL, Hayes DN. The Evolving Role of Radiotherapy for Head and Neck Cancer. Hematol Clin (2020) 34(1):91-108. doi: 10.1016/ j.hoc.2019.08.019

21. Rajendra A, Noronha V, Joshi A, Patil VM, Menon N, Prabhash K. Palliative chemotherapy in head and neck cancer: balancing between beneficial and adverse effects. Expert Rev Anticancer Ther (2020) 20(1):17-29. doi: 10.1080/ 14737140.2020.1708197

22. Gau M, Karabajakian A, Reverdy T, Neidhardt E-M, Fayette J. Induction chemotherapy in head and neck cancers: Results and controversies. Oral Oncol (2019) 95:164-9. doi: 10.1016/j.oraloncology.2019.06.015

23. Tahara M. [The Concept of Platinum-Resistance and Treatment Strategies in Head and Neck Cancer]. Gan To Kagaku Ryoho (2019) 46(5):885-90.

24. Kelland L. The resurgence of platinum-based cancer chemotherapy. Nat Rev Cancer (2007) 7(8):573-84. doi: 10.1038/nrc2167

25. Kareemaghay S, Tavassoli M. Clinical immunotherapeutic approaches for the treatment of head and neck cancer. Int J Oral Maxillofac Surg (2019) 48 (4):419-36. doi: 10.1016/j.ijom.2018.10.012

26. Ward FJ, Dahal LN, Abu-Eid R. On the Road to Immunotherapy-Prospects for Treating Head and Neck Cancers With Checkpoint Inhibitor Antibodies. Front Immunol (2018) 9:2182. doi: 10.3389/fimmu.2018.02182

27. Rothschild U, Muller L, Lechner A, Schlösser HA, Beutner D, Läubli H, et al. Immunotherapy in head and neck cancer - scientific rationale, current treatment options and future directions. Swiss Med Wkly (2018) 148: w14625. doi: 10.4414/smw.2018.14625

28. Burton DR. Antibody: the flexible adaptor molecule. Trends Biochem Sci (1990) 15(2):64-9. doi: 10.1016/0968-0004(90)90178-E

29. Charles A Janeway J, Travers P, Walport M, Shlomchik MJ. The structure of a typical antibody molecule. Immunobiol Immune Syst Health Dis 5th Ed. New York: Garland Science (2001). p. 115-6.

30. Irani SR. 'Moonlighting' surface antigens: a paradigm for autoantibody pathogenicity in neurology? Brain J Neurol (2016) 139(Pt 2):304-6. doi: 10.1093/brain/awv364

31. Al Qaraghuli MM, Kubiak-Ossowska K, Mulheran PA. Thinking outside the Laboratory: Analyses of Antibody Structure and Dynamics within Different
Solvent Environments in Molecular Dynamics (MD) Simulations. Antibodies (2018) 7(3):21. doi: 10.3390/antib7030021

32. Kaplon H, Muralidharan M, Schneider Z, Reichert JM. Antibodies to watch in 2020. $m A$ bs (2020) 12(1):1703531. doi: 10.1080/19420862.2019.1703531

33. Bao B, Ahmad A, Azmi AS, Ali S, Sarkar FH. Overview of cancer stem cells (CSCs) and mechanisms of their regulation: implications for cancer therapy. Curr Protoc Pharmacol (2013) Chapter 14: Unit 14.25. doi: 10.1002/ 0471141755.ph1425s61

34. Tahmasebi E, Alikhani M, Yazdanian A, Yazdanian M, Tebyanian H, Seifalian A. The current markers of cancer stem cell in oral cancers. Life Sci (2020) 249:117483. doi: 10.1016/j.lfs.2020.117483

35. Sun Z, Fu Y-X, Peng H. Targeting tumor cells with antibodies enhances antitumor immunity. Biophys Rep (2018) 4(5):243-53. doi: 10.1007/s41048-0180070-2

36. Zimmermann M, Zouhair A, Azria D, Ozsahin M. The epidermal growth factor receptor (EGFR) in head and neck cancer: its role and treatment implications. Radiat Oncol Lond Engl (2006) 1:11. doi: 10.1186/1748-717X-1-11

37. Sigismund S, Avanzato D, Lanzetti L. Emerging functions of the EGFR in cancer. Mol Oncol (2018) 12(1):3-20. doi: 10.1002/1878-0261.12155

38. Harari PM, Wheeler DL, Grandis JR. Molecular Target Approaches in Head and Neck Cancer: EGFR and Beyond. Semin Radiat Oncol (2009) 19(1):638. doi: 10.1016/.semradonc.2008.09.009

39. Conte A, Sigismund S. Chapter Six - The Ubiquitin Network in the Control of EGFR Endocytosis and Signaling. Prog Mol Biol Transl Sci (2016) 141:225-76. doi: 10.1016/bs.pmbts.2016.03.002

40. Wee P, Wang Z. Epidermal Growth Factor Receptor Cell Proliferation Signaling Pathways. Cancers (2017) 9(5):52. doi: 10.3390/cancers 9050052

41. Lewis TS, Shapiro PS, Ahn NG. Signal transduction through MAP kinase cascades. Adv Cancer Res (1998) 74:49-139. doi: 10.1016/S0065-230X(08)60765-4

42. Morrison DK. MAP kinase pathways. Cold Spring Harb Perspect Biol (2012) 4(11):a011254. doi: 10.1101/cshperspect.a011254

43. Carpenter G, Cohen S. Epidermal growth factor. Annu Rev Biochem (1979) 48:193-216. doi: 10.1146/annurev.bi.48.070179.001205

44. Grandis JR, Tweardy DJ. Elevated levels of transforming growth factor alpha and epidermal growth factor receptor messenger RNA are early markers of carcinogenesis in head and neck cancer. Cancer Res (1993) 53(15):3579-84.

45. Arteaga C. Targeting HER1/EGFR: a molecular approach to cancer therapy. Semin Oncol (2003) 30(3 Suppl 7):3-14. doi: 10.1016/S0093-7754(03)70010-4

46. Rubin Grandis J, Melhem MF, Barnes EL, Tweardy DJ. Quantitative immunohistochemical analysis of transforming growth factor-alpha and epidermal growth factor receptor in patients with squamous cell carcinoma of the head and neck. Cancer (1996) 78(6):1284-92. doi: 10.1002/(SICI) 1097-0142(19960915)78:6<1284::AID-CNCR17>3.0.CO;2-X

47. Raben D, Bianco C, Milas L, Ang KK. Targeted therapies and radiation for the treatment of head and neck cancer: are we making progress? Semin Radiat Oncol (2004) 14(2):139-52. doi: 10.1053/j.semradonc.2003.12.009

48. Vermorken JB, Mesia R, Rivera F, Remenar E, Kawecki A, Rottey S, et al. Platinum-Based Chemotherapy plus Cetuximab in Head and Neck Cancer. N Engl J Med (2008) 359(11):1116-27. doi: 10.1056/NEJMoa0802656

49. Forastiere AA, Metch B, Schuller DE, Ensley JF, Hutchins LF, Triozzi P, et al. Randomized comparison of cisplatin plus fluorouracil and carboplatin plus fluorouracil versus methotrexate in advanced squamous-cell carcinoma of the head and neck: a Southwest Oncology Group study. J Clin Oncol OffJ Am Soc Clin Oncol (1992) 10(8):1245-51. doi: 10.1200/JCO.1992.10.8.1245

50. Lokich J, Anderson N. Carboplatin versus cisplatin in solid tumors: an analysis of the literature. Ann Oncol Off J Eur Soc Med Oncol (1998) 9(1):1321. doi: 10.1023/A:1008215213739

51. Jacobs C, Lyman G, Velez-García E, Sridhar KS, Knight W, Hochster H, et al. A phase III randomized study comparing cisplatin and fluorouracil as single agents and in combination for advanced squamous cell carcinoma of the head and neck. J Clin Oncol Off J Am Soc Clin Oncol (1992) 10(2):257-63. doi: 10.1200/JCO.1992.10.2.257

52. Forastiere AA. Chemotherapy of head and neck cancer. Ann Oncol (1992) 3: S11-4. doi: 10.1093/annonc/3.suppl_3.S11

53. Cetuximab Biosimilars are on the Horizon. Center for Biosimilars. Samantha DiGrande, Center for Biosimilars ${ }^{\circledR}$ (2018). Available at: https://www. centerforbiosimilars.com/news/cetuximab-biosimilars-are-on-the-horizon accessed on 23rd January 2020. 
54. Ferris RL. Immunology and Immunotherapy of Head and Neck Cancer. J Clin Oncol Off J Am Soc Clin Oncol (2015) 33(29):3293-304. doi: 10.1200/ JCO.2015.61.1509

55. Ishida Y, Agata Y, Shibahara K, Honjo T. Induced expression of PD-1, a novel member of the immunoglobulin gene superfamily, upon programmed cell death. EMBO J (1992) 11(11):3887-95. doi: 10.1002/j.14602075.1992.tb05481.x

56. Brunet JF, Denizot F, Luciani MF, Roux-Dosseto M, Suzan M, Mattei MG, et al. A new member of the immunoglobulin superfamily-CTLA-4. Nature (1987) 328(6127):267-70. doi: 10.1038/328267a0

57. Dong C, Juedes AE, Temann UA, Shresta S, Allison JP, Ruddle NH, et al. ICOS co-stimulatory receptor is essential for T-cell activation and function. Nature (2001) 409(6816):97-101. doi: 10.1038/35051100

58. Godfrey WR, Fagnoni FF, Harara MA, Buck D, Engleman EG. Identification of a human OX-40 ligand, a costimulator of $\mathrm{CD} 4+\mathrm{T}$ cells with homology to tumor necrosis factor. J Exp Med (1994) 180(2):757-62. doi: 10.1084/ jem.180.2.757

59. Monney L, Sabatos CA, Gaglia JL, Ryu A, Waldner H, Chernova T, et al. Th1-specific cell surface protein Tim-3 regulates macrophage activation and severity of an autoimmune disease. Nature (2002) 415(6871):536-41. doi: $10.1038 / 415536 \mathrm{a}$

60. Forster MD, Devlin M-J. Immune Checkpoint Inhibition in Head and Neck Cancer. Front Oncol (2018) 8:310. doi: 10.3389/fonc.2018.00310

61. Zak KM, Grudnik P, Magiera K, Dömling A, Dubin G, Holak TA. Structural Biology of the Immune Checkpoint Receptor PD-1 and Its Ligands PD-L1/PDL2. Struct Lond Engl (1993) 2017 0125(8):1163-74. doi: 10.1016/j.str.2017.06.011

62. Chen L, Flies DB. Molecular mechanisms of T cell co-stimulation and coinhibition. Nat Rev Immunol (2013) 13(4):227-42. doi: 10.1038/nri3405

63. Riella LV, Paterson AM, Sharpe AH, Chandraker A. Role of the PD-1 Pathway in the Immune Response. Am J Transpl (2012) 12(10):2575-87. doi: 10.1111/j.1600-6143.2012.04224.x

64. Dong H, Zhu G, Tamada K, Chen L. B7-H1, a third member of the B7 family, co-stimulates T-cell proliferation and interleukin-10 secretion. Nat Med (1999) 5(12):1365-9. doi: 10.1038/70932

65. Latchman Y, Wood CR, Chernova T, Chaudhary D, Borde M, Chernova I, et al. PD-L2 is a second ligand for PD-1 and inhibits T cell activation. Nat Immunol (2001) 2(3):261-8. doi: 10.1038/85330

66. Sharma P, Allison JP. The future of immune checkpoint therapy. Science (2015) 348(6230):56-61. doi: 10.1126/science.aaa8172

67. Lechner A, Schlößer H, Rothschild SI, Thelen M, Reuter S, Zentis P, et al. Characterization of tumor-associated T-lymphocyte subsets and immune checkpoint molecules in head and neck squamous cell carcinoma. Oncotarget (2017) 048(27):44418-33. doi: 10.18632/oncotarget.17901

68. Schoppy DW, Sunwoo JB. Immunotherapy for Head and Neck Squamous Cell Carcinoma. Hematol Oncol Clin North Am (2015) 29(6):1033-43. doi: 10.1016/j.hoc.2015.07.009

69. Cohen EEW, Soulières D, Le Tourneau C, Dinis J, Licitra L, Ahn M-J, et al. Pembrolizumab versus methotrexate, docetaxel, or cetuximab for recurrent or metastatic head-and-neck squamous cell carcinoma (KEYNOTE-040): a randomised, open-label, phase 3 study. Lancet (2019) 393(10167):156-67. doi: S0140-6736(18)31999-8

70. Harrington KJ, Ferris RL, Blumenschein G, Colevas AD, Fayette J, Licitra L, et al. Nivolumab versus standard, single-agent therapy of investigator's choice in recurrent or metastatic squamous cell carcinoma of the head and neck (CheckMate 141): health-related quality-of-life results from a randomised, phase 3 trial. Lancet Oncol (2017) 18(8):1104-15. doi: 10.1016/ S1470-2045(17)30421-7

71. Burtness B, Harrington KJ, Greil R, Soulières D, Tahara M, de Castro G, et al. Pembrolizumab alone or with chemotherapy versus cetuximab with chemotherapy for recurrent or metastatic squamous cell carcinoma of the head and neck (KEYNOTE-048): a randomised, open-label, phase 3 study. Lancet Lond Engl (2019) 394(10212):1915-28. doi: 10.1016/S0140-6736(19)32591-7

72. Napolitano M, Schipilliti FM, Trudu L, Bertolini F. Immunotherapy in head and neck cancer: The great challenge of patient selection. Crit Rev Oncol Hematol (2019) 144:102829. doi: 10.1016/j.critrevonc.2019.102829

73. Seidel JA, Otsuka A, Kabashima K. Anti-PD-1 and Anti-CTLA-4 Therapies in Cancer: Mechanisms of Action, Efficacy, and Limitations. Front Oncol (2018) 28(8):86. doi: 10.3389/fonc.2018.00086
74. Chan DV, Gibson HM, Aufiero BM, Wilson AJ, Hafner MS, Mi Q-S, et al. Differential CTLA-4 expression in human CD4+ versus CD8+ T cells is associated with increased NFAT1 and inhibition of CD4+ proliferation. Genes Immun (2014) 15(1):25-32. doi: 10.1038/gene.2013.57

75. Rotte A. Combination of CTLA-4 and PD-1 blockers for treatment of cancer. J Exp Clin Cancer Res (2019) 38(1):255. doi: 10.1186/s13046-019-1259-z

76. Fife BT, Bluestone JA. Control of peripheral T-cell tolerance and autoimmunity via the CTLA-4 and PD-1 pathways. Immunol Rev (2008) 224(1):166-82. doi: 10.1111/j.1600-065X.2008.00662.x

77. Zhao Y, Yang W, Huang Y, Cui R, Li X, Li B. Evolving Roles for Targeting CTLA-4 in Cancer Immunotherapy. Cell Physiol Biochem (2018) 47(2):72134. doi: $10.1159 / 000490025$

78. Mokyr MB, Kalinichenko T, Gorelik L, Bluestone JA. Realization of the therapeutic potential of CTLA-4 blockade in low-dose chemotherapytreated tumor-bearing mice. Cancer Res (1998) 58(23):5301-4.

79. Stafford F, Ah-See K, Fardy M, Fell K. Organisation and provision of head and neck cancer surgical services in the United Kingdom: United Kingdom National Multidisciplinary Guidelines. J Laryngol Otol (2016) 130(Suppl 2): S5-8. doi: 10.1017/S0022215116000839

80. Bauman JE, Ferris RL. Integrating novel therapeutic monoclonal antibodies into the management of head and neck cancer. Cancer (2014) 120(5):62432. doi: $10.1002 /$ cncr. 28380

81. Whiteside TL. Head and Neck Carcinoma Immunotherapy: Facts and Hopes. Clin Cancer Res Off J Am Assoc Cancer Res (2018) 24(1):6-13. doi: 10.1158/1078-0432.CCR-17-1261

82. Chung KY, Shia J, Kemeny NE, Shah M, Schwartz GK, Tse A, et al. Cetuximab shows activity in colorectal cancer patients with tumors that do not express the epidermal growth factor receptor by immunohistochemistry. J Clin Oncol Off J Am Soc Clin Oncol (2005) 23(9):1803-10. doi: 10.1200/ JCO.2005.08.037

83. Johnson GA, Mannel R, Khalifa M, Walker JL, Wren M, Min K-W, et al. Epidermal Growth Factor Receptor in Vulvar Malignancies and Its Relationship to Metastasis and Patient Survival. Gynecol Oncol (1997) 65 (3):425-9. doi: 10.1006/gyno.1997.4660

84. Bier H, Hoffmann T, Haas I, van Lierop A. Anti-(epidermal growth factor) receptor monoclonal antibodies for the induction of antibody-dependent cell-mediated cytotoxicity against squamous cell carcinoma lines of the head and neck. Cancer Immunol Immunother CII (1998) 46(3):167-73. doi: $10.1007 / \mathrm{s} 002620050475$

85. Blaszczak W, Barczak W, Wegner A, Golusinski W, Suchorska WM. Clinical value of monoclonal antibodies and tyrosine kinase inhibitors in the treatment of head and neck squamous cell carcinoma. Med Oncol Northwood Lond Engl (2017) 34(4):60. doi: 10.1007/s12032-017-0918-1

86. Mehra R, Serebriiskii IG, Dunbrack RL, Robinson MK, Burtness B, Golemis EA. Protein-intrinsic and signaling network-based sources of resistance to EGFR- and ErbB family-targeted therapies in head and neck cancer. Drug Resist Update Rev Comment Antimicrob Anticancer Chemother (2011) 14 (6):260-79. doi: 10.1016/j.drup.2011.08.002

87. Lu Y, Li X, Liang K, Luwor R, Siddik ZH, Mills GB, et al. Epidermal growth factor receptor (EGFR) ubiquitination as a mechanism of acquired resistance escaping treatment by the anti-EGFR monoclonal antibody cetuximab. Cancer Res (2007) 67(17):8240-7. doi: 10.1158/0008-5472.CAN-07-0589

88. Erjala K, Sundvall M, Junttila TT, Zhang N, Savisalo M, Mali P, et al. Signaling via ErbB2 and ErbB3 associates with resistance and epidermal growth factor receptor (EGFR) amplification with sensitivity to EGFR inhibitor gefitinib in head and neck squamous cell carcinoma cells. Clin Cancer Res Off J Am Assoc Cancer Res (2006) 12(13):4103-11. doi: 10.1158/ 1078-0432.CCR-05-2404

89. Misale S, Yaeger R, Hobor S, Scala E, Janakiraman M, Liska D, et al. Emergence of KRAS mutations and acquired resistance to anti-EGFR therapy in colorectal cancer. Nature (2012) 486(7404):532-6. doi: 10.1038/nature11156

90. Braig F, Kriegs M, Voigtlaender M, Habel B, Grob T, Biskup K, et al. Cetuximab Resistance in Head and Neck Cancer Is Mediated by EGFR-K521 Polymorphism. Cancer Res (2017) 0177(5):1188-99. doi: 10.1158/00085472.CAN-16-0754

91. Johansson A-C, Ansell A, Jerhammar F, Lindh MB, Grénman R, MunckWikland E, et al. Cancer-Associated Fibroblasts Induce Matrix Metalloproteinase-Mediated Cetuximab Resistance in Head and Neck 
Squamous Cell Carcinoma Cells. Mol Cancer Res (2012) 10(9):1158-68. doi: 10.1158/1541-7786.MCR-12-0030

92. O-charoenrat P, Rhys-Evans P, Modjtahedi H, Eccles SA. Vascular endothelial growth factor family members are differentially regulated by cerbB signaling in head and neck squamous carcinoma cells. Clin Exp Metastasis (2000) 18(2):155-61. doi: 10.1023/a:1006764100867

93. Sen M, Joyce S, Panahandeh M, Li C, Thomas SM, Maxwell J, et al. Targeting Stat3 abrogates EGFR inhibitor resistance in cancer. Clin Cancer Res Off J Am Assoc Cancer Res (2012) 18(18):4986-96. doi: 10.1158/1078-0432.CCR-12-0792

94. Vassallo R, Kroening PR, Parambil J, Kita H. Nicotine and oxidative cigarette smoke constituents induce immune-modulatory and proinflammatory dendritic cell responses. Mol Immunol (2008) 45(12):33219. doi: 10.1016/j.molimm.2008.04.014

95. Wheeler DL, Dunn EF, Harari PM. Understanding resistance to EGFR inhibitors-impact on future treatment strategies. Nat Rev Clin Oncol (2010) 7(9):493-507. doi: 10.1038/nrclinonc.2010.97

96. Vermorken JB, Stöhlmacher-Williams J, Davidenko I, Licitra L, Winquist E, Villanueva C, et al. Cisplatin and fluorouracil with or without panitumumab in patients with recurrent or metastatic squamous-cell carcinoma of the head and neck (SPECTRUM): an open-label phase 3 randomised trial. Lancet Oncol (2013) 14(8):697-710. doi: 10.1016/S1470-2045(13)70181-5

97. Baas JM, Krens LL, Guchelaar H-J, Ouwerkerk J, de Jong FA, Lavrijsen APM, et al. Recommendations on management of EGFR inhibitor-induced skin toxicity: a systematic review. Cancer Treat Rev (2012) 38(5):505-14. doi: 10.1016/j.ctrv.2011.09.004

98. Segaert S, Van Cutsem E. Clinical signs, pathophysiology and management of skin toxicity during therapy with epidermal growth factor receptor inhibitors. Ann Oncol Off J Eur Soc Med Oncol (2005) 16(9):1425-33. doi: 10.1093/annonc/mdi279

99. Specenier P, Vermorken JB. Cetuximab: its unique place in head and neck cancer treatment. Biol Targets Ther (2013) 7:77-90. doi: 10.2147/BTT.S43628

100. Walsh L, Gillham C, Dunne M, Fraser I, Hollywood D, Armstrong J, et al. Toxicity of cetuximab versus cisplatin concurrent with radiotherapy in locally advanced head and neck squamous cell cancer (LAHNSCC). Radiother Oncol (2011) 98(1):38-41. doi: 10.1016/j.radonc.2010.11.009

101. Shah M, Jomaa MK, Ferrarotto R, Yeung S-CJ, Hanna EY, Reyes-Gibby CC. Serious immune-related adverse events in patients with head and neck cancer after checkpoint blockade: Systematic review. Head Neck (2019) 41 (11):4036-50. doi: 10.1002/hed.25911

102. Xie X, O'Neill W, Pan Q. Immunotherapy for head and neck cancer: the future of treatment? Expert Opin Biol Ther (2017) 17(6):701-8. doi: 10.1080/ 14712598.2017.1315100

103. Nivolumab for treating squamous cell carcinoma of the head and neck after platinum-based chemotherapy. The National Institute for Health and Care Excellence (NICE) (2017). Available at: https://www.nice.org.uk/guidance/ TA490/chapter/1-Recommendations.

104. Thakor AS, Gambhir SS. Nanooncology: the future of cancer diagnosis and therapy. CA Cancer J Clin (2013) 63(6):395-418. doi: 10.3322/caac.21199

105. Song S, Qin Y, He Y, Huang Q, Fan C, Chen H-Y. Functional nanoprobes for ultrasensitive detection of biomolecules. Chem Soc Rev (2010) 39(11):423443. doi: 10.1039/c000682n

106. Zhang Y, Li M, Gao X, Chen Y, Liu T. Nanotechnology in cancer diagnosis: progress, challenges and opportunities. J Hematol OncolJ Hematol Oncol (2019) 12(1):137. doi: 10.1186/s13045-019-0833-3

107. Chen X-J, Zhang X-Q, Liu Q, Zhang J, Zhou G. Nanotechnology: a promising method for oral cancer detection and diagnosis. J Nanobiotechnol (2018) 16(1):52. doi: 10.1186/s12951-018-0378-6

108. Gmeiner WH, Ghosh S. Nanotechnology for cancer treatment. Nanotechnol Rev (2015) 3(2):111-22. doi: 10.1515/ntrev-2013-0013

109. Maeda $H$. The enhanced permeability and retention (EPR) effect in tumor vasculature: the key role of tumor-selective macromolecular drug targeting. Adv Enzyme Regul (2001) 41:189-207. doi: 10.1016/S0065-2571(00)00013-3

110. Maeda H. Macromolecular therapeutics in cancer treatment: the EPR effect and beyond. J Control Release Off J Control Release Soc (2012) 164(2):138-44. doi: 10.1016/j.jconrel.2012.04.038

111. Shchors K, Evan G. Tumor angiogenesis: cause or consequence of cancer? Cancer Res (2007) 67(15):7059-61. doi: 10.1158/0008-5472.CAN-07-2053

112. Weis SM, Cheresh DA. Tumor angiogenesis: molecular pathways and therapeutic targets. Nat Med (2011) 17(11):1359-70. doi: 10.1038/nm.2537
113. Byrne JD, Betancourt T, Brannon-Peppas L. Active targeting schemes for nanoparticle systems in cancer therapeutics. Adv Drug Delivery Rev (2008) 60(15):1615-26. doi: 10.1016/j.addr.2008.08.005

114. Nie S. Understanding and overcoming major barriers in cancer nanomedicine. Nanomed (2010) 5(4):523-8. doi: 10.2217/nnm.10.23

115. Llevot A, Astruc D. Applications of vectorized gold nanoparticles to the diagnosis and therapy of cancer. Chem Soc Rev (2012) 41(1):242-57. doi: 10.1039/C1CS15080D

116. Petryayeva E, Krull UJ. Localized surface plasmon resonance: Nanostructures, bioassays and biosensing-A review. Anal Chim Acta (2011) 706(1):8-24. doi: 10.1016/j.aca.2011.08.020

117. El-Sayed MA. Some Interesting Properties of Metals Confined in Time and Nanometer Space of Different Shapes. Acc Chem Res (2001) 34(4):257-64. doi: $10.1021 /$ ar960016n

118. Marycz K, Kolankowski J, Grzesiak J, Hecold M, Rac O, Teterycz H. Application of Gold Nanoparticles of Different Concentrations to Improve the Therapeutic Potential of Autologous Conditioned Serum: Potential Implications for Equine Regenerative Medicine. J Nanomaterials (2015) 2015:e521207. doi: 10.1155/2015/521207

119. Patra CR, Bhattacharya R, Mukhopadhyay D, Mukherjee P. Application of Gold Nanoparticles for Targeted Therapy in Cancer. Vol. 4, No. 2 (Valencia, California: American Scientific Publishers) (2008). p. 99-134(34). Available at: https://www.ingentaconnect.com/content/asp/jbn/2008/00000004/ 00000002/art00001.

120. Kim HS, Lee DY. Photothermal therapy with gold nanoparticles as an anticancer medication. J Pharm Investig (2017) 47(1):19-26. doi: 10.1007/ s40005-016-0292-6

121. Abadeer NS, Murphy CJ. Recent Progress in Cancer Thermal Therapy Using Gold Nanoparticles. J Phys Chem C. (2016) 120(9):4691-716. doi: 10.1021/ acs.jpcc.5b11232

122. Yao C, Zhang L, Wang J, He Y, Xin J, Wang S, et al. Gold Nanoparticle Mediated Phototherapy for Cancer. J Nanomaterials (2016) 2016:e5497136. doi: 10.1155/2016/5497136

123. Jaque D, Maestro LM, del Rosal B, Haro-Gonzalez P, Benayas A, Plaza JL, et al. Nanoparticles for photothermal therapies. Nanoscale (2014) 6 (16):9494-530. doi: 10.1039/C4NR00708E

124. Betzer O, Ankri R, Motiei M, Popovtzer R. Theranostic Approach for Cancer Treatment: Multifunctional Gold Nanorods for Optical Imaging and Photothermal Therapy. J Nanomaterials (2015) 2015:e646713. doi: $10.1155 / 2015 / 646713$

125. Zhao Y, Chen H, Chen X, Hollett G, Gu Z, Wu J, et al. Targeted nanoparticles for head and neck cancers: overview and perspectives. WIREs Nanomed Nanobiotechnol (2017) 9(6):e1469. doi: 10.1002/wnan.1469

126. Li Z, Chen Y, Yang Y, Yu Y, Zhang Y, Zhu D, et al. Recent Advances in Nanomaterials-Based Chemo-Photothermal Combination Therapy for Improving Cancer Treatment. Front Bioeng Biotechnol (2019) 7:293. doi: 10.3389/fbioe.2019.00293

127. Shukla N, Singh B, Kim H-J, Park M-H, Kim K. Combinational Chemotherapy and Photothermal Therapy Using a Gold Nanorod Platform for Cancer Treatment. Part Part Syst Charact (2020) 37 (8):2000099. doi: 10.1002/ppsc.202000099

128. Roa W, Zhang X, Guo L, Shaw A, Hu X, Xiong Y, et al. Gold nanoparticle sensitize radiotherapy of prostate cancer cells by regulation of the cell cycle. Nanotechnology (2009) 20(37):375101. doi: 10.1088/0957-4484/20/37/375101

129. Yao C, Zhang L, Wang J, He Y, Xin J, Wang S, et al. Gold Nanoparticle Mediated Phototherapy for Cancer. J Nanomaterials (2016) 2016:e5497136. doi: 10.1155/2016/5497136

130. Naslund I, Wersall P, Castellanos E, Beskow C, Nyrén S. Fine-needle Marker for IGRT, a New Fiducial Gold Anchor for High-precision Radiotherapy. Int J Radiat Oncol Biol Phys (2009) 75(3):S608-9. doi: 10.1016/ j.ijrobp.2009.07.1392

131. Li Z, Huang H, Tang S, Li Y, Yu X-F, Wang H, et al. Small gold nanorods laden macrophages for enhanced tumor coverage in photothermal therapy. Biomaterials (2016) 74:144-54. doi: 10.1016/j.biomaterials.2015.09.038

132. Chirico G, Pallavicini P, Borzenkov M. Physical Properties of Gold Nanostars. In: G Chirico, M Borzenkov, P Pallavicini, editors. Gold Nanostars: Synthesis, Properties and Biomedical Application. Cham: Springer International Publishing Springer Briefs in Materials (2015). p. 25-42. doi: 10.1007/978-3-319-20768-1_2 
133. Safaee SMR, Janipour M, Karami MA. Modeling and analysis of optical properties of a gold nanoring based on electric and magnetic dipoles. Appl Opt (2015) 54(28):8313-7. doi: 10.1364/AO.54.008313

134. Cobley CM, Au L, Chen J, Xia Y. Targeting gold nanocages to cancer cells for photothermal destruction and drug delivery. Expert Opin Drug Deliv (2010) 7(5):577-87. doi: 10.1517/17425240903571614

135. Hatef A, Fortin-Deschênes S, Boulais E, Lesage F, Meunier M. Photothermal response of hollow gold nanoshell to laser irradiation: Continuous wave, short and ultrashort pulse. Int J Heat Mass Transf (2015) 89:866-71. doi: 10.1016/j.ijheatmasstransfer.2015.05.071

136. Link S, El-Sayed MA. Shape and size dependence of radiative, non-radiative and photothermal properties of gold nanocrystals. Int Rev Phys Chem (2000) 19(3):409-53. doi: 10.1080/01442350050034180

137. Orendorff CJ, Sau TK, Murphy CJ. Shape-dependent plasmon-resonant gold nanoparticles. Small Weinh Bergstr Ger (2006) 2(5):636-9. doi: 10.1002/ smll.200500299

138. Boyer D, Tamarat P, Maali A, Lounis B, Orrit M. Photothermal Imaging of Nanometer-Sized Metal Particles Among Scatterers. Science (2002) 297 (5584):1160-3. doi: 10.1126/science.1073765

139. Smitha SL, Gopchandran KG, Smijesh N, Philip R. Size-dependent optical properties of Au nanorods. Prog Nat Sci Mater Int (2013) 23(1):36-43. doi: 10.1016/j.pnsc.2013.01.005

140. Pérez-Juste J, Pastoriza-Santos I, Liz-Marzán LM, Mulvaney P. Gold nanorods: Synthesis, characterization and applications. Coord Chem Rev (2005) 249(17):1870-901. doi: 10.1016/j.ccr.2005.01.030

141. El-Sayed IH, Huang X, El-Sayed MA. Selective laser photo-thermal therapy of epithelial carcinoma using anti-EGFR antibody conjugated gold nanoparticles. Cancer Lett (2006) 239(1):129-35. doi: 10.1016/j.canlet.2005.07.035

142. Huang X, El-Sayed IH, Qian W, El-Sayed MA. Cancer Cell Imaging and Photothermal Therapy in the Near-Infrared Region by Using Gold Nanorods. J Am Chem Soc (2006) 128(6):2115-20. doi: 10.1021/ja057254a

143. Huang X, Qian W, El-Sayed IH, El-Sayed MA. The potential use of the enhanced nonlinear properties of gold nanospheres in photothermal cancer therapy. Lasers Surg Med (2007) 39(9):747-53. doi: 10.1002/lsm.20577

144. El-Sayed MA, Shabaka AA, El-Shabrawy OA, Yassin NA, Mahmoud SS, ElShenawy SM, et al. Tissue Distribution and Efficacy of Gold Nanorods Coupled with Laser Induced Photoplasmonic Therapy in Ehrlich Carcinoma Solid Tumor Model. PLoS One (2013) 8(10):e76207. doi: 10.1371/ journal.pone.0076207

145. Abdoon AS, Al-Ashkar EA, Kandil OM, Shaban AM, Khaled HM, El Sayed MA, et al. Efficacy and toxicity of plasmonic photothermal therapy (PPTT) using gold nanorods (GNRs) against mammary tumors in dogs and cats. Nanomed Nanotechnol Biol Med (2016) 12(8):2291-7. doi: 10.1016/ j.nano.2016.07.005

146. Ali MRK, Ibrahim IM, Ali HR, Selim SA, El-Sayed MA. Treatment of natural mammary gland tumors in canines and felines using gold nanorods-assisted plasmonic photothermal therapy to induce tumor apoptosis. Int J Nanomed (2016) 11:4849-63. doi: 10.2147/IJN.S109470

147. Yang W, Liang H, Ma S, Wang D, Huang J. Gold nanoparticle based photothermal therapy: Development and application for effective cancer treatment. Sustain Mater Technol (2019) 22:e0109. doi: 10.1016/j.susmat.2019.e00109

148. Dreaden EC, Austin LA, Mackey MA, El-Sayed MA. Size matters: gold nanoparticles in targeted cancer drug delivery. Ther Deliv (2012) 3(4):45778. doi: $10.4155 /$ tde. 12.21
149. Jana NR, Gearheart L, Murphy CJ. Wet Chemical Synthesis of High Aspect Ratio Cylindrical Gold Nanorods. J Phys Chem B (2001) 105(19):4065-7. doi: 10.1021/jp0107964

150. Nikoobakht B, El-Sayed MA. Preparation and Growth Mechanism of Gold Nanorods (NRs) Using Seed-Mediated Growth Method. Chem Mater (2003) 15(10):1957-62. doi: 10.1021/cm0207321

151. Ali MRK, Snyder B, El-Sayed MA. Synthesis and Optical Properties of Small $\mathrm{Au}$ Nanorods Using a Seedless Growth Technique. Langmuir (2012) 28 (25):9807-15. doi: 10.1021/la301387p

152. Grabinski C, Schaeublin N, Wijaya A, D'Couto H, Baxamusa SH, HamadSchifferli K, et al. Effect of Gold Nanorod Surface Chemistry on Cellular Response. ACS Nano (2011) 5(4):2870-9. doi: 10.1021/nn103476x

153. Yu C, Varghese L, Irudayaraj J. Surface Modification of Cetyltrimethylammonium Bromide-Capped Gold Nanorods to Make Molecular Probes. Langmuir (2007) 23(17):9114-9. doi: 10.1021/la701111e

154. Wijaya A, Hamad-Schifferli K. Ligand Customization and DNA Functionalization of Gold Nanorods via Round-Trip Phase Transfer Ligand Exchange. Langmuir (2008) 24(18):9966-9. doi: 10.1021/la8019205

155. Omura N, Uechi I, Yamada S. Comparison of plasmonic sensing between polymer- and silica-coated gold nanorods. Anal Sci Int J Jpn Soc Anal Chem (2009) 25(2):255-9. doi: 10.2116/analsci.25.255

156. You Q, Sun Q, Yu M, Wang J, Wang S, Liu L, et al. BSA-Bioinspired Gadolinium Hybrid-Functionalized Hollow Gold Nanoshells for NIRF/PA/ CT/MR Quadmodal Diagnostic Imaging-Guided Photothermal/ Photodynamic Cancer Therapy. ACS Appl Mater Interfaces (2017) 9 (46):40017-30. doi: 10.1021/acsami.7b11926

157. von Maltzahn G, Park J-H, Agrawal A, Bandaru NK, Das SK, Sailor MJ, et al. Computationally guided photothermal tumor therapy using long-circulating gold nanorod antennas. Cancer Res (2009) 69(9):3892-900. doi: 10.1158/ 0008-5472.CAN-08-4242

158. Joshi PP, Yoon SJ, Hardin WG, Emelianov S, Sokolov KV. Conjugation of antibodies to gold nanorods through Fc portion: synthesis and molecular specific imaging. Bioconjug Chem (2013) 24(6):878-88. doi: 10.1021/bc3004815

159. Jazayeri MH, Amani H, Pourfatollah AA, Pazoki-Toroudi $H$, Sedighimoghaddam B. Various methods of gold nanoparticles (GNPs) conjugation to antibodies. Sens Bio Sens Res (2016) 9:17-22. doi: 10.1016/ j.sbsr.2016.04.002

160. McLachlan A, Singh K, McAlduff M, Gerrard Marangoni D, Shortall S, Wettig SD. m-s-m cationic gemini and zwitterionic surfactants - a thermodynamic analysis of their mixed micelle formation. RSC Adv (2020) 10(6):3221-32. doi: 10.1039/C9RA09432F

161. Kuperkar K, Patriati A, Putra EGR, Singh K, Marangoni DG, Bahadur P. Microstructural study of cetyltrimethylammonium bromide/1-butanol / salt / water system - SANS and 2D-NOESY analysis. Can J Chem (2012) 90(3):314-20. doi: 10.1139/v11-155

Conflict of Interest: The author is employed by the company SiMologics Ltd.

Copyright (C) 2020 Al Qaraghuli. This is an open-access article distributed under the terms of the Creative Commons Attribution License (CC BY). The use, distribution or reproduction in other forums is permitted, provided the original author(s) and the copyright owner(s) are credited and that the original publication in this journal is cited, in accordance with accepted academic practice. No use, distribution or reproduction is permitted which does not comply with these terms. 